\title{
GSK-3: functional insights from cell biology and animal models
}

\section{Oksana Kaidanovich-Beilin ${ }^{1}$ and James Robert Woodgett ${ }^{1,2 *}$}

' Samuel Lunenfeld Research Institute, Mount Sinai Hospital, Toronto, ON, Canada

${ }^{2}$ Department of Medical Biophysics, University of Toronto, Toronto, ON, Canada

\section{Edited by:}

Richard Scott Jope, University of Alabama at Birmingham, USA

\section{Reviewed by:}

Urs Albrecht, University of Fribourg, Switzerland

Hagit Eldar-Finkelman, Tel Aviv

University, Israel

*Correspondence:

Oksana Kaidanovich-Beilin, Samuel Lunenfeld Research Institute, Mount

Sinai Hospital, 600 University Avenue, Room 983, Toronto, ON, Canada M5G $1 \times 5$.

e-mail:beilin@/unenfeld.ca; James Robert Woodgett, Samuel Lunenfeld Research Institute, Mount Sinai Hospital, 600 University Avenue, Room 982, Toronto, ON, Canada M5G $1 \times 5$.

e-mail:woodgett@mshri.on.ca
Glycogen synthase kinase-3 (GSK-3) is a widely expressed and highly conserved serine/threonine protein kinase encoded in mammals by two genes that generate two related proteins: GSK-3 $\alpha$ and GSK-3 $\beta$. GSK-3 is active in cells under resting conditions and is primarily regulated through inhibition or diversion of its activity. While GSK-3 is one of the few protein kinases that can be inactivated by phosphorylation, the mechanisms of GSK-3 regulation are more varied and not fully understood. Precise control appears to be achieved by a combination of phosphorylation, localization, and sequestration by a number of GSK-3binding proteins. GSK-3 lies downstream of several major signaling pathways including the phosphatidylinositol 3' kinase pathway, the Wnt pathway, Hedgehog signaling and Notch. Specific pools of GSK-3, which differ in intracellular localization, binding partner affinity, and relative amount are differentially sensitized to several distinct signaling pathways and these sequestration mechanisms contribute to pathway insulation and signal specificity. Dysregulation of signaling pathways involving GSK-3 is associated with the pathogenesis of numerous neurological and psychiatric disorders and there are data suggesting GSK-3 isoform-selective roles in several of these. Here, we review the current knowledge of GSK3 regulation and targets and discuss the various animal models that have been employed to dissect the functions of GSK-3 in brain development and function through the use of conventional or conditional knockout mice as well as transgenic mice. These studies have revealed fundamental roles for these protein kinases in memory, behavior, and neuronal fate determination and provide insights into possible therapeutic interventions.

\section{Keywords: GSK-3, signal transduction, animal models, behavior}

\section{CHARACTERIZATION OF GSK-3}

Glycogen synthase kinase-3 (ATP:protein phosphotransferase, E.C. 2.7.1.37) is a serine/threonine protein kinase, belonging to the CMCG family of proline-directed kinases (Cyclin-dependent kinases (CDKs), Mitogen-activated protein kinases (MAPKs), Glycogen synthase kinases (GSKs), and CDK-like kinases (CLKs). GSK-3 is a monomeric, second messenger-independent protein kinase that was first discovered through its ability to activate the ATP-Mg-dependent form of type- 1 protein phosphatase ("Factor $\mathrm{A}^{\prime \prime}$ ) and to phosphorylate the key rate-limiting metabolic enzyme that catalyzes the last step of glycogen synthesis, glycogen synthase (GS; Embi et al., 1980; Rylatt et al., 1980; Vandenheede et al., 1980).

GSK-3 is a highly conserved protein kinase and has orthologs in plants, fungi, worms, flies, sea squirts, and vertebrates: isoenzymes from species as distant as flies and humans display more than $90 \%$ sequence similarity within the protein kinase domain (reviewed in Ali et al., 2001). GSK-3/ $\mathrm{F}_{\mathrm{A}}$ has been purified by several groups (Hemmings et al., 1982; Woodgett and Cohen, 1984; Tung and Reed, 1989), and was molecularly cloned based on partial peptide sequencing (Woodgett, 1990). Two rat brain cDNAs encoding GSK-3 were isolated that corresponded to isoenzymes designated GSK-3 alpha $(\alpha)$ and GSK-3 beta $(\beta)$, with apparent $M_{\mathrm{r}}$ of $51,000 \mathrm{Da}$ (483 aa in humans) and $47,000 \mathrm{Da}$ (433 aa), respectively (Woodgett, 1990). Genes encoding GSK-3 $\alpha$ and $\beta$ are located on mouse chromosome 7/human chromosome 19 and on mouse chromosome 16/human chromosome 3 , respectively (see Figure 1; based on http://genome.ucsc.edu). Mammalian GSK-3 is therefore represented by two paralogous proteins. Overall, GSK$3 \alpha$ and $\beta$ share $85 \%$ overall sequence homology, including $98 \%$ amino acid sequence identity within their kinase domains (Woodgett, 1990). This latter fact makes the likelihood of development of small molecule inhibitors that can discriminate the two forms very unlikely. Despite their catalytic domain similarity, GSK-3 isoenzymes diverge in their $\mathrm{N}$ - and C-termini. For example, the two gene products share only $36 \%$ identity in the last $76 \mathrm{C}$-terminal residues (Woodgett, 1990). GSK-3 $\alpha$ has an extended glycine-rich $\mathrm{N}$-terminal region that has been proposed to function as a pseudosubstrate (Dajani et al., 2001). Interestingly, while many species such as fish, amphibians, and lizards harbor both isoforms, birds have only GSK-3 $\beta$ and appear to have selectively lost GSK-3 $\alpha$ (Alon et al., 2011).

GSK-3 is expressed ubiquitously and both gene products are found in virtually all mammalian tissues. The kinase is highly expressed in the brain (Woodgett, 1990; Yao et al., 2002; PerezCostas et al., 2010), both in neurons and glia (Ferrer et al., 2002). In the developing brain, the presence of GSK-3 is high at E18 and 

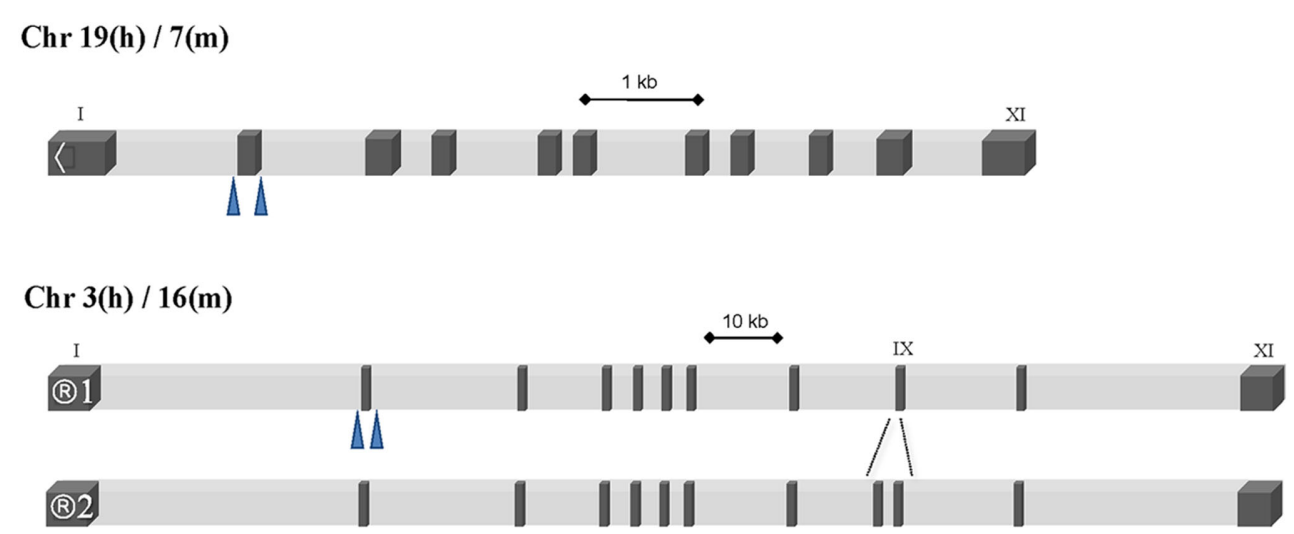

$\triangle$ - Site of LoxP sequences in floxed alleles

FIGURE 1 | Intron/exon structure of the two mammalian GSK-3 genes indicating the differential splice of GSK-3 $\beta$ and location of LoxP recombination sites in conditional alleles.

peaks at P8, decreasing somewhat after that period (Takahashi et al., 1994). In adult brain, GSK-3 $\alpha$ is especially abundant in the hippocampus, cerebral cortex, striatum, and cerebellum (based on Allen Brain Atlas). GSK-3 $\beta$ is expressed in nearly all brain regions, although there are marked regional differences of GSK-3 $\beta$ mRNA levels in the human brain (Pandey et al., 2009). As a caution, the glycine-rich (and hence purine-rich) region of GSK-3 $\alpha$ may distort comparative analysis of RNA expression between it and GSK-3 $\beta$.

In certain cell types of the brain, alternative splicing between exon 8 and 9 of GSK-3 $\beta$ leads to the generation of an additional "long" form containing a 13 amino acid insert within the catalytic domain (GSK-3 $\beta 2$; see Figure 1). This insert is located between residues 303 and 304 of GSK-3 $\beta$, and is flanked by two proximal $\alpha$ helices of kinase subdomains X and XI (Hanks and Hunter, 1995; Mukai et al., 2002). This alternatively spliced isoform of GSK-3 $\beta$ in rodents (Mukai et al., 2002; Yao et al., 2002) and in human (Lau et al., 1999; Schaffer et al., 2003; Kwok et al., 2005) has been implicated in neuronal-specific functions. The short form of GSK-3 $\beta$ is ubiquitously expressed in the body, including the developing and adult nervous system (Takahashi et al., 1994; Leroy and Brion, 1999). By contrast, GSK-3 $\beta 2$ is predominantly expressed in the neural tissues, with highest levels in the developing brain and persistence into adulthood (Mukai et al., 2002; Wood-Kaczmar et al., 2009).

\section{GSK-3 REGULATION}

An unusual feature of GSK-3 is that the kinase displays high activity in cells under resting/unstimulated conditions (Sutherland et al., 1993; Stambolic and Woodgett, 1994; Woodgett, 1994) and is one of few protein kinases that is inhibited by extracellular signals that induce a rapid and reversible increase in serine phosphorylation of GSK-3 causing a decrease in enzymatic activity. For example, growth factor, insulin, or serum treatment decreases
GSK-3 activity by 30-70\% within 10 min (Sutherland et al., 1993; Welsh and Proud, 1993; Saito et al., 1994; Stambolic and Woodgett, 1994; Sutherland and Cohen, 1994; Cross et al., 1995; EldarFinkelman et al., 1995). The mechanisms of GSK-3 regulation are varied and not yet fully understood; precise control appears to be achieved by a combination of phosphorylation, localization, and sequestration by a number of GSK-3-binding proteins (reviewed in Frame and Cohen, 2001; Doble and Woodgett, 2003; Jope and Johnson, 2004; Kockeritz et al., 2006).

\section{REGULATION THROUGH PHOSPHORYLATION}

GSK-3 is dual specificity kinase differentially regulated by tyrosine and serine/threonine phosphorylation. The activity of GSK-3 is positively regulated by phosphorylation on a "T loop" tyrosine residue within subdomain VIII (Tyr279 for GSK-3 $\alpha$ and Tyr216 for GSK-3ß; Hughes et al., 1993; Lochhead et al., 2006). The kinase is negatively regulated by $\mathrm{N}$-terminal phosphorylation of serine residues of the enzyme (Ser21 for GSK-3 $\alpha$ and Ser9 for GSK3ß; Sutherland et al., 1993; Sutherland and Cohen, 1994). p38 MAPK can also inactivate GSK-3 $\beta$ via phosphorylation within its C-terminal region at Ser389 and Thr390 (Thornton et al., 2008). p38 MAPK-mediated phosphorylation of GSK-3 $\beta$ occurs primarily in the brain and thymocytes (Thornton et al., 2008). In addition, Thr43 of GSK-3 $\beta$ may be phosphorylated by Erk, resulting in GSK-3 inhibition (Ding et al., 2005).

From the crystal structure, it has been proposed that unphosphorylated Tyr276/Tyr216 act to block the access of primed substrates (as discussed below). Indeed, the structure of phosphorylated GSK-3 $\beta$ (Bax et al., 2001) shows that phosphorylated Tyr216 undergoes a conformational change that allows substrates to bind the enzyme. Previous studies, however, led to conflicting conclusions as to whether tyrosine phosphorylation of GSK-3 is catalyzed by GSK-3 itself (autophosphorylation) or by a distinct tyrosine kinase (Hughes et al., 1993; Kim et al., 1999; Lesort et al., 1999; 
Wang et al., 2003; Cole et al., 2004a). In support of the autophosphorylation model, at least in mammals, Lochhead et al. (2006) showed that newly synthesized GSK-3 $\beta$ autophosphorylated itself on tyrosine and that this event could be prevented by exposure to GSK-3 inhibitors.

In contrast to tyrosine phosphorylation, regulation of $\mathrm{N}$ terminal serine phosphorylation is only conserved in GSK-3 homologs from mammals, Xenopus, and Drosophila, but not in yeast, higher plants, Dictyostelium, or Caenorhabditis elegans. The phosphorylation state of serine residues of both isoenzymes is dynamic, involving phosphorylation by several protein kinases and dephosphorylation by protein phosphatase-1 (PP-1; Sutherland et al., 1993; Saito et al., 1994; Stambolic and Woodgett, 1994; Cross et al., 1995; Eldar-Finkelman et al., 1995; Welsh et al., 1998; Zhang et al., 2003). N-terminal domain serine phosphorylation of GSK-3 $\alpha$ and GSK-3 $\beta$ leads to inhibition of its activity (Sutherland et al., 1993; Saito et al., 1994; Stambolic and Woodgett, 1994; Cross et al., 1995; Eldar-Finkelman et al., 1995; Welsh et al., 1998; Grimes and Jope, 2001; Zhang et al., 2003). Phosphorylation of GSK-3 within its N-terminal region creates a "pseudosubstrate" which intramolecularly binds to a "phosphoprotein binding pocket" within the active site of the kinase, suppressing activity by occluding primed substrate access to the binding pocket (Frame et al., 2001).

This inhibitory mechanism is induced by agonists such as neurotrophins and growth factors that activate protein kinases that act on the N-terminal domain of GSK-3 such as PKB/Akt, p90rsk,
cyclic-AMP-dependent protein kinase, p70 S6 kinase, as well as regulators of phosphatase-1 (Sutherland et al., 1993; Stambolic and Woodgett, 1994; Alessi et al., 1996; Li et al., 2000; Svenningsson et al., 2003; see Figure 2). For example, insulin leads to inhibition of GSK-3 via insulin receptor substrate-1-dependent induction of phosphatidylinositol $3^{\prime}$ kinase (PI3K), which then stimulates PKB/Akt (Cross et al., 1995). GSK-3 has previously been shown to catalyze serine phosphorylation of IRS-1 and IRS-2, interfering with receptor-mediated tyrosine phosphorylation by the insulin receptor, effectively attenuating insulin receptor signaling via a negative feedback loop (Eldar-Finkelman and Krebs, 1997; Sharfi and Eldar-Finkelman, 2008; Figure 2). Moreover, recent studies have revealed novel bi-directionality in the interaction of $\mathrm{PKB} / \mathrm{Akt}$ and GSK-3 whereby genetic ablation of GSK-3 significantly suppresses PKB/Akt phosphorylation (Lu et al., 2011), indicating a possible novel feedback loop in PKB/Akt/MAPK network (Figure 2).

Growth factors, such as EGF and PDGF can also inhibit GSK-3 activity through the phosphatidylinositol $3^{\prime}$ kinase (PI3K) pathway (Stambolic and Woodgett, 1994; Shaw and Cohen, 1999), as well as through induction of the MAPK cascade (Saito et al., 1994; Brady et al., 1998). Ser9/21 phosphorylation of GSK-3 can be modified by amino acid deprivation through mammalian target of rapamycin (mTOR; Armstrong et al., 2001; Krause et al., 2002; Terruzzi et al., 2002) or in response to agonists that elevate the intracellular levels of cAMP through cyclic-AMP-dependent protein kinase (PKA; Fang et al., 2000; Li et al., 2000; Figure 2). The PKA-anchoring

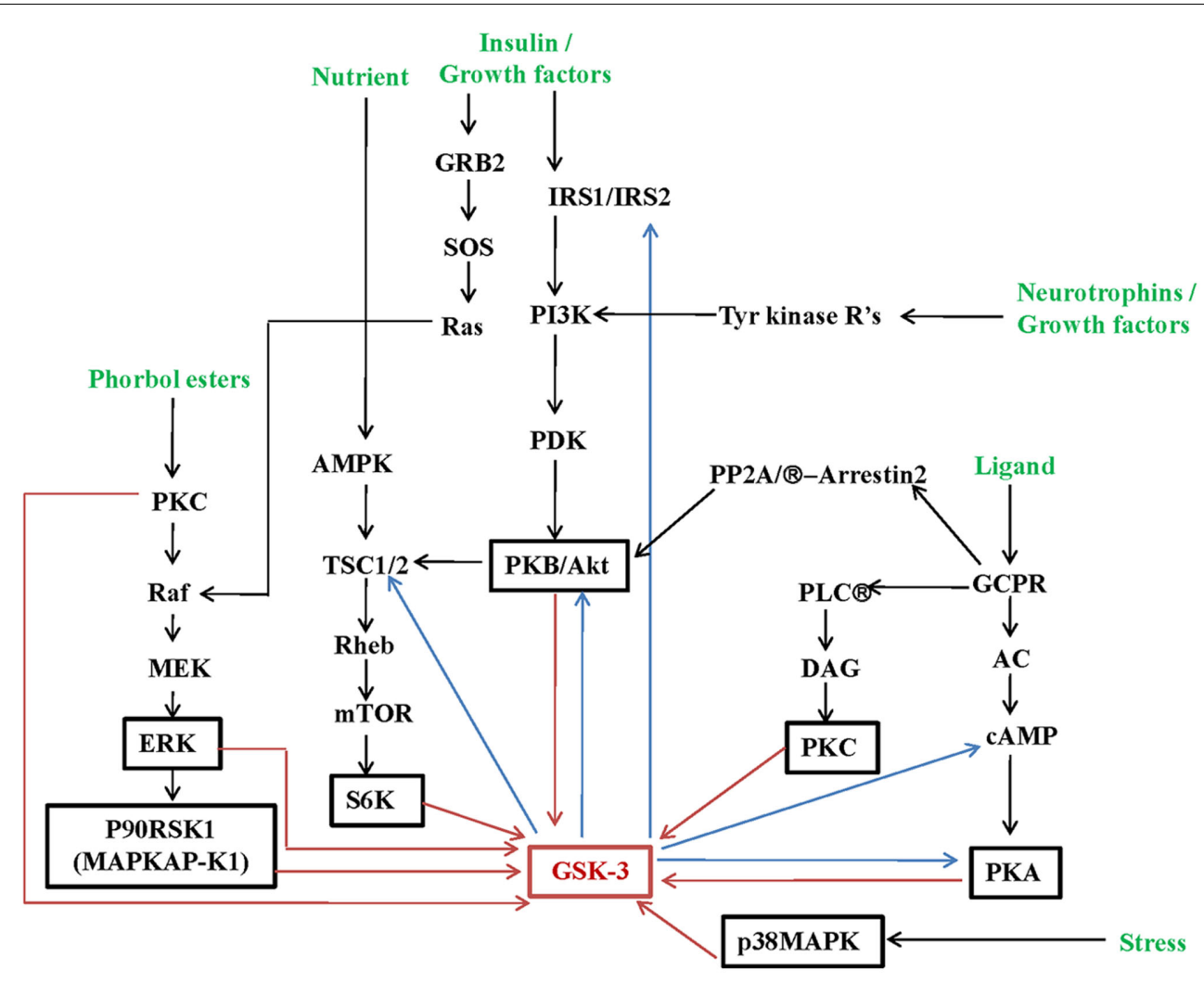

FIGURE 2 | Summary of regulatory signaling inputs into GSK-3. 
protein 220 binds both GSK-3 and PKA and hence facilitates GSK3 phosphorylation by this protein kinase (Tanji et al., 2002). PKC agonists can also regulate GSK-3 (Ballou et al., 2001; Fang et al., 2002), however certain PKCs may preferentially regulate GSK-3 $\beta$ but not GSK-3 $\alpha$ (Goode et al., 1992).

\section{REGULATION THROUGH COMPLEX FORMATION}

Wnts are secreted glycolipoproteins that activate canonical and non-canonical ( $\beta$-catenin independent) Wnt signaling cascades, which are essential for early embryonic patterning, cell fate, cellular polarity, cell movement, cell proliferation as well as adult homeostasis in both vertebrates and invertebrates (Logan and Nusse, 2004; Moon et al., 2004; Salinas, 2005; MacDonald et al., 2009). The canonical Wnt signaling pathway employs a distinct mechanism for regulating GSK-3 that is independent of $\mathrm{N}$-terminal domain serine phosphorylation or tyrosine phosphorylation and, instead, relies on protein:protein interactions and intracellular sequestration. Thus, the canonical Wnt pathway comprises phylogenetically conserved proteins: the Wnt receptor, Frizzled; co-receptor, low-density lipoprotein receptor-related protein (LRP) 5/6; scaffolding proteins, Disheveled (Dvl), Axin, Adenomatous polyposis coli (APC) and GSK-3, $\beta$-catenin, and casein kinase-1 (CK1; see Figure 3).

In cells a small fraction $(<5-10 \%)$ of cellular GSK-3 is associated with a scaffolding protein termed Axin (Lee et al., 2003; Benchabane et al., 2008). These molecules are joined by others to create a "destruction complex" comprising Axin, APC, CK1, GSK-3, and $\beta$-catenin (Zeng et al., 1997; Hart et al., 1998; Ikeda et al., 1998). Within this machine, CK1 phosphorylates Ser45 of $\beta$-catenin, which generates a priming site for subsequent GSK-3 phosphorylation on Thr41 (Amit et al., 2002; Hagen and VidalPuig, 2002; Hagen et al., 2002; Liu et al., 2002; Sakanaka, 2002; Yanagawa et al., 2002) and subsequently Ser37 and Ser33; resulting in $\beta$-catenin recognition by $\beta$ - $\operatorname{TrCP}$ (an E3 ubiquitin ligase subunit), and subsequent ubiquitin-mediated proteasomal degradation of $\beta$-catenin (Aberle et al., 1997; Amit et al., 2002; Liu et al., 2002; He et al., 2004). This results in the maintenance of very low levels of $\beta$-catenin within the cytoplasm and nucleus of cells (significant amounts of $\beta$-catenin are associated, in epithelial cells, with the cadherin adhesion molecules but this fraction is effectively sequestered and does not play a role in Wnt signaling). In addition to $\beta$-catenin, both Axin and APC are phosphorylated by GSK-3. Phosphorylation of Axin by GSK-3 increases its stability and binding to $\beta$-catenin (Ikeda et al., 1998; Jho et al., 1999; Yamamoto et al., 1999). Phosphorylation of APC increases its affinity to $\beta$-catenin (Rubinfeld et al., 1996). Both events promote $\beta$-catenin phosphorylation and degradation complex stability.

Wnt ligand induces binding of the seven-pass transmembrane receptor Frizzled and the LRP5/6 co-receptor which leads to the recruitment of Dvl and induction of LRP 5/6 phosphorylation by GSK-3 and CK1. This creates a high affinity binding site for Axin (He et al., 2004; Zeng et al., 2005; Mi et al., 2006; Niehrs and Shen, 2010). Recruitment of Axin to the receptor proteins results in functional dissolution of the destruction complex allowing the stabilization and accumulation of $\beta$-catenin. The now stable $\beta$ catenin translocates to the nucleus where it binds with members of the TCF/LEF family of DNA-binding proteins, resulting in transcriptional activation of certain targets genes.

$\beta$-catenin is dephosphorylated primarily by protein phosphatase (PP) 2A (Su et al., 2008). APC may also act to interfere with PP2A dephosphorylation of $\beta$-catenin (Su et al., 2008). APC also facilitates Axin degradation (Lee et al., 2003; Takacs et al., 2008). PP-1 activity leads to dephosphorylation of Axin, antagonizing CK1 phosphorylation as well as negatively regulating GSK-3-Axin binding, promoting complex disassembly (Luo et al., 2007).

Several molecular mechanisms have been proposed to explain how canonical Wnt signaling may interfere with GSK-3dependent phosphorylation of $\beta$-catenin (reviewed in Kimelman and Xu, 2006). For example, the intracellular domain of LRP6 may act as a direct inhibitor of GSK-3 (Mi et al., 2006; Cselenyi et al., 2008; Piao et al., 2008; Wu et al., 2009). A recent study suggested an important role of multi-vesicular endosomes in the canonical Wnt pathway (Taelman et al., 2010). In cells harboring a constitutively activated mutant of LRP6, sequestration of GSK-3 into these membrane-bound organelles was observed, leading to insulation of GSK-3 from other components of the pathway (Taelman et al., 2010). This trafficking machinery required $\beta$-catenin which formed a feed-forward loop by facilitating GSK-3 sequestration (Taelman et al., 2010). Whether this mechanism plays a role in physiological Wnt signaling has yet to be determined.

Both mammalian isoforms of GSK-3 function equivalently in Wnt signaling and are entirely redundant (Doble et al., 2007). Indeed, retention of just one of the four GSK-3 alleles is sufficient to maintain low levels of $\beta$-catenin in the absence of $\mathrm{Wnt}$, reiterating the fact that only a small fraction of GSK-3 is tightly associated with Axin and therefore relevant to Wnt signaling.

GSK-3 can also associate with other proteins, e.g., GSK-3binding protein (GBP or FRAT; Li et al., 1999; Fraser et al., 2002) and GSKIP (Chou et al., 2006); however, the roles of FRAT and GSKIP in GSK-3 biology have yet to be defined. GSK-3 is also a part of interacting complex of proteins involved in Hedgehog $(\mathrm{Hh})$ pathway, regulating a key transcription factor of $\mathrm{Hh}$ signaling - cubitus interruptus (Ci; Price and Kalderon, 2002).

\section{REGULATION THOUGH INTRACELLULAR LOCALIZATION}

In addition to binding proteins in the cytoplasm, there are differences in patterns of subcellular localization of the GSK-3 isozymes (Hoshi et al., 1995; Franca-Koh et al., 2002; Bijur and Jope, 2003). GSK-3 is largely considered as a cytoplasmic protein, but the kinase can also be detected in the nucleus and mitochondria where it is more active compared with the larger cytoplasmic fraction (Bijur and Jope, 2003). Nuclear localization of GSK-3 is dynamic and dependent on the cell cycle (being highest during S-phase; Diehl et al., 1998). Activity is also rapidly increased during apoptosis (Bijur and Jope, 2001). The mechanisms governing intracellular localization of GSK-3 are not fully elucidated. Activated PKB/Akt has been reported to decrease nuclear levels of GSK-3 (Bijur and Jope, 2001). Binding of FRAT 1 to GSK-3 facilitates nuclear export (Franca-Koh et al., 2002). The viral tumor-associated latent nuclear antigen binds GSK-3 and acts to enrich it in the nuclear fraction (Fujimuro et al., 2003). As mentioned previously, GSK$3 \alpha$ has an N-terminal extension compared to GSK-3 $\beta$. One role of this extra domain may be to provide a level of regulation to 


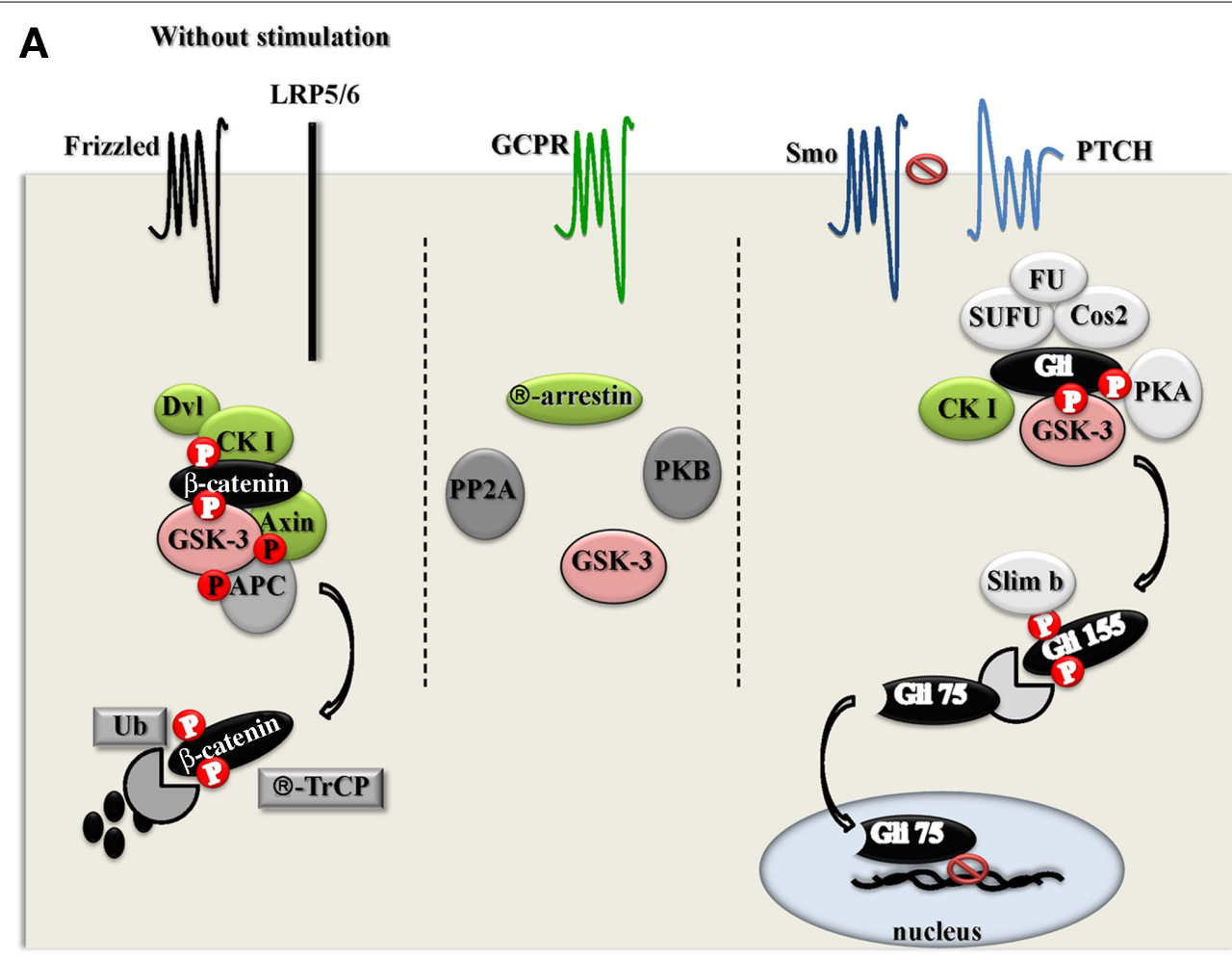

B

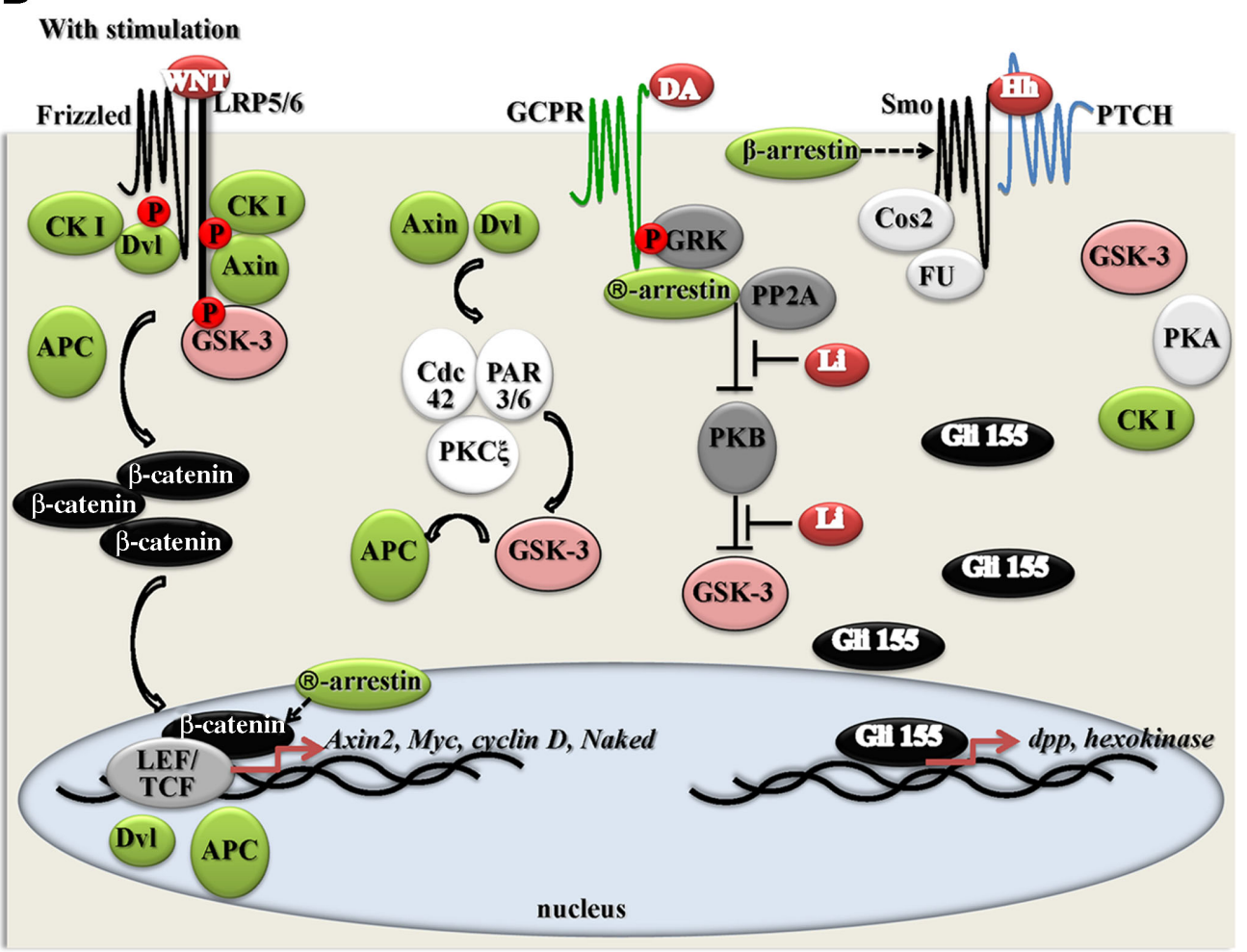

FIGURE 3 | Interaction between different intracellular pools of GSK-3 and protein complexes, involved into Wnt, Hedgehog (Hh), GCPR, and PAR3/6-Cdc42-PKC pathways. (A); resting conditions. (B); activated conditions. 
nuclear transport of this isoform (Azoulay-Alfaguter et al., 2011). Notably, deletion of N-terminus of GSK-3 beta reduces its nucleus accumulation (Meares and Jope, 2007). These studies indicate that at least a fraction of GSK-3 may be regulated by intracellular compartmental shuttling.

The finding that GSK-3 acts downstream of multiple signaling pathways that have distinct effects on cells and tissues presents a conundrum. How might signal selectivity be achieved if a protein common to multiple pathways was a required intermediary? The elegant cellular solution to this is to fractionate GSK-3 between scaffolding proteins or other structures such that each system has its own population of GSK-3 molecules "assigned" to it. This effectively insulates the signals and requires that the GSK-3 subpopulations do not intermingle or exchange. It is still an open question why so many important pathways evolved with a common component, a subject of speculative commentary (McNeill and Woodgett, 2010).

\section{GSK-3 SUBSTRATES}

The determination of the crystal structure of GSK-3 $\beta$ provided further insight into the molecular nature of the regulation of GSK3 and its predilection for primed, pre-phosphorylated, substrates (Dajani et al., 2001; ter Haar et al., 2001). GSK-3 shares common features with other protein kinases and has a small $\mathrm{N}$-terminal lobe mostly consisting of $\beta$-sheets and a large C-terminal lobe essentially formed of $\alpha$-helices (Noble et al., 2005). The ATP-binding pocket is located between the two lobes and is so highly conserved between the two isoforms that discrimination between the two protein kinases by an ATP analog-based inhibitor is highly unlikely (Bain et al., 2007).

GSK-3 is one of only a handful of the over 500 known protein kinases that has a strong (500- to 1000 -fold) preference for substrates that are already primed by phosphorylation at a proximal serine/threonine to the GSK-3 target residue (Thomas et al., 1999). The phosphorylated residue within the presumptive substrate slots into to a "phosphate-binding" pocket that comprises three crucial basic residues - Lys205, Arg96, and Arg180 (Bax et al., 2001; Dajani et al., 2001; ter Haar et al., 2001). These three residues are conserved in all GSK-3 homologs identified to date, suggesting conservation of the priming phosphate-binding site and the substrate specificity of GSK-3 in all organisms. Binding of the priming phosphate of the substrate to this pocket on GSK-3 induces a conformational change, aligning the substrate for subsequent phosphorylation.

The majority of GSK-3 substrates exhibit an absolute requirement for prior phosphorylation by another kinase at a "priming" residue located C-terminal to the site of subsequent phosphorylation by GSK-3 (Fiol et al., 1987). GSK-3-catalyzed phosphorylation of these substrates occurs at the fourth (Fiol et al., 1990) or fifth (Cole et al., 2006) serine or threonine residue $\mathrm{N}$-terminal to the primed site $\left(\mathrm{pS} / \mathrm{T}_{1} \mathrm{XXXpS} / \mathrm{T}_{2}\right)$, where the first $\mathrm{pS} / \mathrm{T}_{1}$ (Ser or Thr) is the target residue, $\mathrm{X}$ is any amino acid (but often Pro), and the last $\mathrm{pS} / \mathrm{T}_{2}$ is the site for priming phosphorylation. Thus, the primed Ser/Thr is recognized by the positively charged "binding pocket" on GSK-3 which facilitates the correct orientation of the substrate within the active site of the kinase. Several protein kinases have been shown to act as priming enzymes for GSK-3 phosphorylation, including CDK-5 (Sengupta et al., 1997; Noble et al., 2003; Li et al., 2006), PAR-1 (Nishimura et al., 2004), casein kinase-1 (Amit et al., 2002), casein kinase-2 (Picton et al., 1982; DePaoli-Roach et al., 1983), PKA (Singh et al., 1995), and PKC (Liu et al., 2003). In the case of several substrates, the residue phosphorylated by GSK-3 acts to prime an additional Ser/Thr residue N-terminal to it. This can lead to a zippering effect where multiple residues become phosphorylated by GSK-3. Certain substrates apparently dodge the requirement for prior phosphorylation including c-Jun (Boyle et al., 1991), cMyc (Saksela et al., 1992), histone H1.5 (Happel et al., 2009), and MARK2/PAR-1 (Kosuga et al., 2005; Timm et al., 2008). In these cases, acidic residues or peptide conformations may substitute for the effect of the priming phosphate.

To prove that an in vitro identified protein is an in vivo physiological substrate of GSK-3 the target has to meet several criteria (Frame and Cohen, 2001). These include phosphorylation of the protein at the appropriate residues by the protein kinase in vitro and under conditions known to modulate that kinase in vivo and selective reduction in those phosphorylation sites upon treatment with a specific inhibitor of the protein kinase (or via gene knockout/RNAi). To date, over 100 cytoplasmic and nuclear proteins have been identified as substrates of GSK-3 although not all of these meet the Frame and Cohen criteria as bona fide targets (reviewed in Doble and Woodgett, 2003; Jope and Johnson, 2004; Kockeritz et al., 2006; Sutherland, 2011; see Table 1).

With respect to biological processes, GSK-3 substrates may be classified into several groups of proteins/transcriptional factors/regulatory enzymes that have roles in processes such as metabolism, cellular architecture, gene expression, neurobiological processes, synaptogenesis, neurodevelopment, axonal growth and polarity, immune response, circadian rhythms, and neuronal/cellular survival (reviewed in Frame and Cohen, 2001; Doble and Woodgett, 2003; Jope and Johnson, 2004; Kockeritz et al., 2006; Sutherland, 2011; see Table 1).

\section{GSK-3 SUBSTRATES RELATED TO CIRCADIAN RHYTHMS}

Circadian (from the Latin circa diem meaning "about a day") rhythms occur with a periodicity of about $24 \mathrm{~h}$ and enable organisms to adapt and anticipate environmental changes. Circadian control provides an evolutionary advantage to organisms in adapting their behavior and physiology to the appropriate time of day (reviewed in Wijnen and Young, 2006; Sahar and Sassone-Corsi, 2009). Feeding behavior, sleep-wake cycles, hormonal levels, and body temperature are just a few examples of physiological circadian rhythms. Dysregulation of the cycle is associated with the onset and development of numerous human diseases, including sleep disorders, depression, and dementia.

From a molecular standpoint, circadian rhythms are regulated by transcriptional and post-translational feedback loops generated by a set of interplaying "clock" proteins. The positive limb of the mammalian clock machinery is comprised of CLOCK and BMAL1, which are transcription factors that heterodimerize through their PAS domains and induce the expression of clockcontrolled genes by binding to their promoters at E-boxes. Cryptochromes (Cry 1, Cry2) and Period genes (Per1, Per2, Per3) are clock-controlled genes that encode proteins that form the 
Table 1 | GSK-3 substrates.

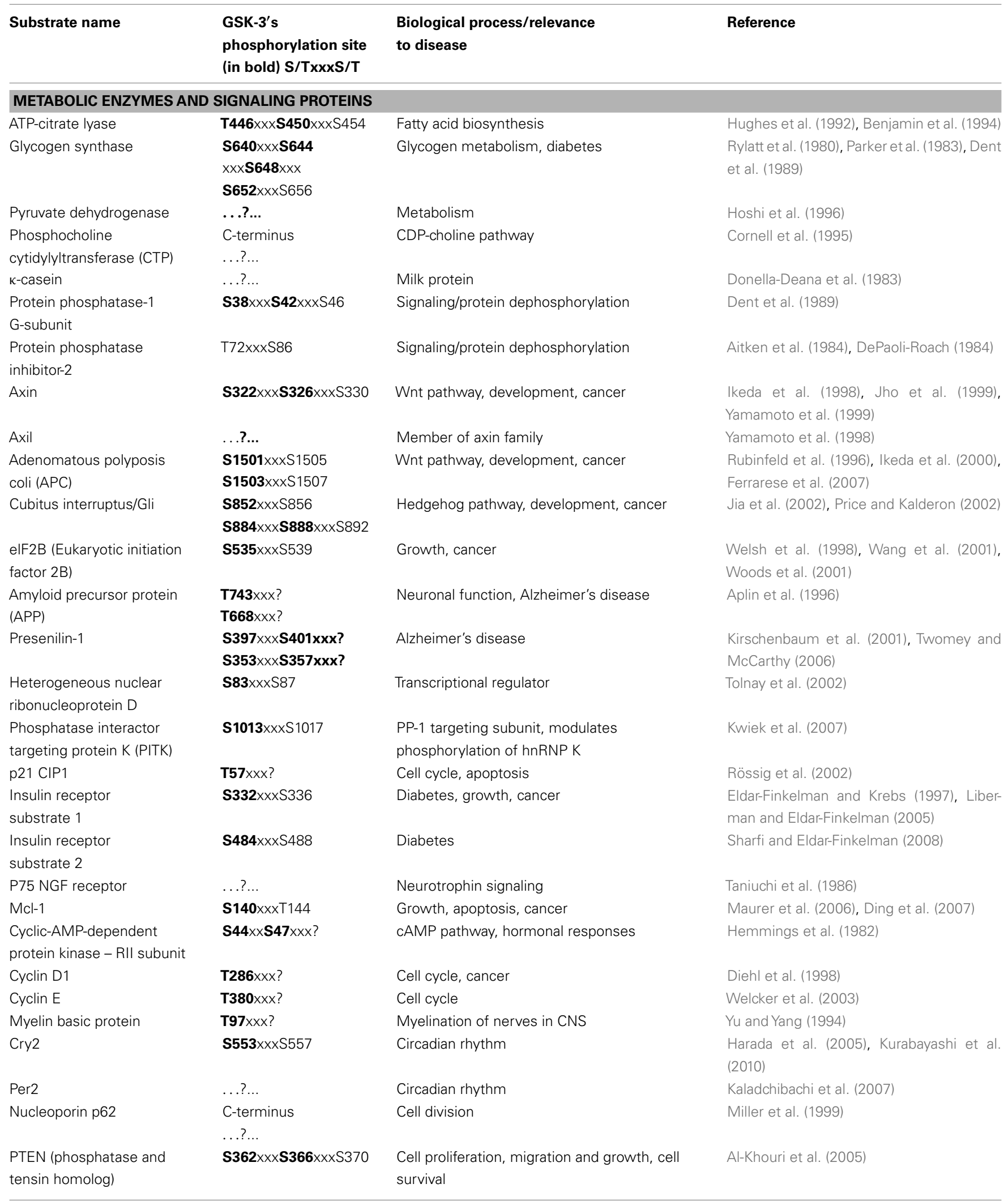


Table 1 | Continued

\begin{tabular}{|c|c|c|c|}
\hline Substrate name & $\begin{array}{l}\text { GSK-3'S } \\
\text { phosphorylation site } \\
\text { (in bold) S/TxxxS/T }\end{array}$ & $\begin{array}{l}\text { Biological process/relevance } \\
\text { to disease }\end{array}$ & Reference \\
\hline $\begin{array}{l}\text { TSC2 (tuberous sclerosis } \\
\text { 2)/Tuberin }\end{array}$ & $\begin{array}{l}\mathbf{S 1 3 3 7} \times x x \\
\mathbf{S 1 3 4 1} \times x \times S 1345\end{array}$ & Tumor suppressor & Inoki et al. (2006) \\
\hline CDC25 (cell division cycle) & s76xxxT80 & Cell cycle, cancer & Kang et al. (2008) \\
\hline RBL2/p130 & 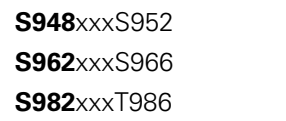 & Growth, cell cycle, cancer & Litovchick et al. (2004) \\
\hline $\begin{array}{l}\text { Voltage dependent anion } \\
\text { channel }\end{array}$ & T51 xxxT55 & Apoptosis, cancer & Pastorino et al. (2005) \\
\hline $\begin{array}{l}\text { Calcipressin/RCN1 } \\
\text { (regulators of calcineurin) }\end{array}$ & $\mathbf{S 1 1 3} \times x \times S 117$ & $\begin{array}{l}\text { Neuronal regulator of calcineurin, growth, } \\
\text { Alzheimer's disease, down syndrome }\end{array}$ & Hilioti et al. (2004) \\
\hline Gephyrin & S270xxx? & GABA transmission, neuronal functions & Tyagarajan et al. (2011) \\
\hline Mixed lineage kinase-3 & S789xxx S793xxx? & $\begin{array}{l}\text { c-Jun and p38 MAPK pathways, apoptosis, } \\
\text { neurodegenerative disease }\end{array}$ & Mishra et al. (2007) \\
\hline OMA-1 & T339xxxT239 & Oocyte maturation & Nishi and Lin (2005) \\
\hline p27Kip1 & $\ldots ? \ldots$ & Cell cycle regulator & Surjit and Lal (2007) \\
\hline $\begin{array}{l}\text { Polypyrimidine } \\
\text { track-binding } \\
\text { protein-associated-splicing } \\
\text { factor (PSF) }\end{array}$ & T687 & Alternative splicing, $T$ cell function/activation & Heyd and Lynch (2010) \\
\hline Dynamin I & T774 $\times x \times T 778$ & Endocytosis, neuronal function & Hong et al. (1998), Clayton et al. (2010) \\
\hline Kinesin light chains (KLCs) & S611 $x x \times S 615 x x x ?$ & Axonal transport, mitosis, meiosis & Morfini et al. (2002) \\
\hline $\begin{array}{l}\text { Microtubule-associated } \\
\text { protein 1B }\end{array}$ & $\begin{array}{l}\text { S1260xxx? } \\
\text { T1265xxx? } \\
\text { S1388xxxS1392 }\end{array}$ & Neuronal functions & $\begin{array}{l}\text { Lucas et al. (1998), Trivedi et al. (2005), } \\
\text { Scales et al. (2009) }\end{array}$ \\
\hline $\begin{array}{l}\text { Microtubule-associated } \\
\text { protein } 2 \mathrm{C}\end{array}$ & $\begin{array}{l}T 1620 \times x x ? \\
T 1623 \times x x ?\end{array}$ & Neuronal functions & Sánchez et al. (2000) \\
\hline Tau & $\begin{array}{l}\text { S208 } x x x T 212 \\
\text { T231 } x x x T 235 x x x ? \\
\text { S396xxx? } \\
\text { S404 } x x x ?\end{array}$ & $\begin{array}{l}\text { Microtubule stabilization, neuronal functions, } \\
\text { Alzheimer's disease }\end{array}$ & $\begin{array}{l}\text { Hanger et al. (1992), Yang et al. (1993), } \\
\text { Woods et al. (2001), Cho and Johnson } \\
\text { (2004) }\end{array}$ \\
\hline Paxillin & $\mathbf{S 1 2 6 x \times x} 130$ & Cell adhesion and migration & Cai et al. (2006) \\
\hline $\begin{array}{l}\text { Collapsin response } \\
\text { mediator protein } 2\end{array}$ & $\begin{array}{l}\text { T509xxxT514 } \times x x \\
\text { S518xxxS522 }\end{array}$ & $\begin{array}{l}\text { Neuronal functions, axonal growth, neuronal } \\
\text { polarity, Alzheimer's disease }\end{array}$ & Cole et al. (2004b), Yoshimura et al. (2005) \\
\hline $\begin{array}{l}\text { Collapsin response } \\
\text { mediator protein } 4\end{array}$ & $\begin{array}{l}\text { T509xxxT514 } \times x x \\
\text { S518 } x \times x \text { S522 }\end{array}$ & Neuronal function, axonal growth & Cole et al. (2004b), Alabed et al. (2010) \\
\hline
\end{tabular}


Table 1 | Continued

\begin{tabular}{|c|c|c|c|}
\hline Substrate name & $\begin{array}{l}\text { GSK-3's } \\
\text { phosphorylation site } \\
\text { (in bold) S/TxxxS/T }\end{array}$ & $\begin{array}{l}\text { Biological process/relevance } \\
\text { to disease }\end{array}$ & Reference \\
\hline Neurofilament L & $\begin{array}{l}\text { S502 } x \times x \text { S506 } x x x ? \\
\text { S603 } x x x ?\end{array}$ & $\begin{array}{l}\text { Cell cytoskeleton, axonal growth, axonal } \\
\text { diameter }\end{array}$ & $\begin{array}{l}\text { Guan et al. (1991); Yang et al. (1995), Sasaki } \\
\text { et al. (2002) }\end{array}$ \\
\hline Neurofilament $\mathrm{H}$ & S493 $x x x ?$ & & \\
\hline Ninein & $\ldots ? \ldots$ & $\begin{array}{l}\text { Centrosomal functions, brain development, } \\
\text { tumorigenesis }\end{array}$ & Hong et al. (2000), Howng et al. (2004) \\
\hline $\begin{array}{l}\text { Telokin kinase-related } \\
\text { protein }\end{array}$ & S15xxx? & $\begin{array}{l}\text { Stabilization of smooth muscle myosin } \\
\text { filaments }\end{array}$ & Krymsky et al. (2001) \\
\hline $\begin{array}{l}\text { CLIP-associated protein } 1 \\
\text { (CLASP 1) }\end{array}$ & $\ldots .594-614 \ldots$ & Neuronal functions & $\begin{array}{l}\text { Wittmann and Waterman-Storer (2005), } \\
\text { Kumar et al. (2009) }\end{array}$ \\
\hline Focal adhesion kinase & S722xxxS726 & Cell cycle, survival, migration, cancer & Bianchi et al. (2005) \\
\hline $\begin{array}{l}\text { Microtubule } \\
\text { affinity-regulating } \\
\text { kinase-2/PAR-1 }\end{array}$ & S212xxx? & Neuronal function, axonal growth & Kosuga et al. (2005), Timm et al. (2008) \\
\hline Polycystin 2 & S76xxxS80 & Growth, survival, polycystic kidney disease & Streets et al. (2006) \\
\hline Dystrophin & $\ldots ? \ldots$ & Cytoskeleton of muscle fibers & Michalak et al. (1996) \\
\hline $\begin{array}{l}\text { Stathmin/oncoprotein } 18 \\
\text { (STMN1) }\end{array}$ & S31 $x \times x ?$ & Microtubule polymerization and dynamics & Moreno and Avila (1998) \\
\hline von Hippel-Lindau (VHL) & $\mathbf{S 6 8} \times x \times S 72$ & Oxygen sensor, tumor of CNS, kidney, eyes & Hergovich et al. (2006) \\
\hline \multicolumn{4}{|l|}{ TRANSCRIPTION FACTORS } \\
\hline$\beta$-catenin & $\begin{array}{l}\text { S33 } x \times x \text { S37 } x x x \\
\text { T41 } x \times x \text { S45 }\end{array}$ & Wnt pathway, development, cancer & Yost et al. (1996), Ikeda et al. (1998) \\
\hline $\begin{array}{l}\text { Cyclic AMP response } \\
\text { element-binding protein } \\
\text { (CREB) }\end{array}$ & $\mathbf{S 1 2 9} \times x \times S 133$ & $\begin{array}{l}\text { Metabolism, neuronal function, memory } \\
\text { formation, diabetes }\end{array}$ & $\begin{array}{l}\text { Fiol et al. (1994), Bullock and Habener } \\
\text { (1998) }\end{array}$ \\
\hline GATA4 & $\begin{array}{l}\ldots 2-116 \ldots \\
\ldots 2-205 \ldots\end{array}$ & $\begin{array}{l}\text { Embryogenesis, myocardial differentiation } \\
\text { and function }\end{array}$ & Morisco et al. (2001) \\
\hline Hypoxia-inducible factor-1 & $\begin{array}{l}\text { S551 } x \times x \text { T555xxx? } \\
\text { S589 } x \times x ?\end{array}$ & Growth, cancer & Mottet et al. (2003), Flugel et al. (2007) \\
\hline Heat shock factor-1 (HSF1) & S303xxxS307 & Stress (heat) response & Chu et al. (1996) \\
\hline c-Myc & S62xxx? & Growth, cancer, oncogenes & Saksela et al. (1992), Sears et al. (2000) \\
\hline L-myc & T58xxxS62 & & \\
\hline $\begin{array}{l}\mathrm{N} \text {-myc downstream } \\
\text { regulated gene } 1\end{array}$ & $\begin{array}{l}\text { T342xxxT346 } \\
\text { T352xxxT356 } \\
\text { T362 } \times x \times T 366\end{array}$ & $\begin{array}{l}\text { Stress and hormone response, cell growth } \\
\text { and differentiation, cancer }\end{array}$ & Murray et al. (2004) \\
\hline C-Jun, Jun B, Jun D & T239xxxT243 & Growth and cancer & $\begin{array}{l}\text { Boyle et al. (1991), Nikolakaki et al. (1993), } \\
\text { Woodgett et al. (1993), Morton et al. (2003) }\end{array}$ \\
\hline c-Myb & T572xxx? & Hematopoiesis, tumorigenesis. & Kitagawa et al. (2009) \\
\hline $\begin{array}{l}\text { Nuclear factor of activated } \\
T \text { cells c (NFATc) }\end{array}$ & $\begin{array}{l}\text { SP2 domain } \\
\text { SP3 domain }\end{array}$ & Immune system response & $\begin{array}{l}\text { Beals et al. (1997), Neal and Clipstone } \\
\text { (2001) }\end{array}$ \\
\hline
\end{tabular}


Table 1 | Continued

\begin{tabular}{|c|c|c|c|}
\hline Substrate name & $\begin{array}{l}\text { GSK-3's } \\
\text { phosphorylation site } \\
\text { (in bold) S/TxxxS/T }\end{array}$ & $\begin{array}{l}\text { Biological process/relevance } \\
\text { to disease }\end{array}$ & Reference \\
\hline $\begin{array}{l}\text { Nuclear factor } \kappa \text { B (NF-кB) } \\
\text { p65subunit } \\
\text { precursorp105 of p50 } \\
\text { subunit }\end{array}$ & $\begin{array}{l}\text { S468 } x \times x ? \\
\text { S903 } x \times x \text { S907 } x x x ?\end{array}$ & $\begin{array}{l}\text { Stress response, immune response, synaptic } \\
\text { plasticity and memory, cancer, inflammation, } \\
\text { autoimmune diseases }\end{array}$ & Demarchi et al. (2003), Buss et al. (2004) \\
\hline Notch $1 \mathrm{C}$ & $\ldots ? \ldots$ & $\begin{array}{l}\text { Development, cell-cell communication, } \\
\text { cancer. }\end{array}$ & Foltz et al. (2002), Espinosa et al. (2003) \\
\hline p53 & $\begin{array}{l}\text { S33 } x \times x \text { S37 } \\
\text { S315xxx? } \\
\text { S376 } x \times x ?\end{array}$ & Cell cycle regulator, cancer. & Turenne and Price (2001), Qu et al. (2004) \\
\hline Snail & $\begin{array}{l}\mathbf{S} 97 \times x \times \mathbf{S} 101 \\
\mathbf{S 1 0 8} \times x \times \mathbf{S 1 1 2} \times x x \\
\mathbf{S 1 1 6} \times x \times \mathbf{S 1 2 0} \times x \times ?\end{array}$ & $\begin{array}{l}\text { Epithelial to mesenchymal transition } \\
\text { regulator }\end{array}$ & Zhou et al. (2004) \\
\hline Activator protein 1 (AP-1) & $\ldots ? \ldots$ & Differentiation, proliferation, apoptosis & de Groot et al. (1993) \\
\hline Glucocorticoid receptor & T171 $x \times x ?$ & $\begin{array}{l}\text { Stress and immune response, development, } \\
\text { metabolism }\end{array}$ & Rogatsky et al. (1998) \\
\hline $\begin{array}{l}\text { Microphthalmia-associated } \\
\text { transcription factor }\end{array}$ & S298xxx & Melanocyte and osteoclast development & Takeda et al. (2000) \\
\hline NeuroD & $\ldots ? \ldots$ & Central nervous system development & Moore et al. (2002) \\
\hline BCL-3 & S394xxxS398 & Growth and cancer & Viatour et al. (2004) \\
\hline Bmal1 & S17 $x x x \mathbf{T} 21 x x x ?$ & Circadian rhythm & Sahar et al. (2010) \\
\hline Rev-erb $\alpha$ & S55 $x x \times$ S59 $x x x ?$ & Circadian rhythm & Yin et al. (2006) \\
\hline Timeless & $\ldots ? \ldots$ & Circadian rhythm & Martinek et al. (2001) \\
\hline Clock & S427 $x \times x S 431$ & Circadian rhythm & Spengler et al. (2009) \\
\hline SMAD1 & $\ldots ? \ldots$ & Embryonic pattern formation, TGF $\beta$ signaling & Fuentealba et al. (2007) \\
\hline SMAD3 & T66 $x \times x ?$ & TGF $\beta$ signaling, development, cancer & Guo et al. (2008) \\
\hline Neurogenin 2 (Ngn2) & $\begin{array}{l}\text { S231 } x x x ? \\
\text { S234 } x x x ?\end{array}$ & $\begin{array}{l}\text { Neuronal function, motor neurons, } \\
\text { development }\end{array}$ & Ma et al. (2008) \\
\hline $\begin{array}{l}\text { BCLAF1 (Bcl-2 interacting } \\
\text { transcriptional repressor) }\end{array}$ & S531xxx? & Apoptosis, cancer & Linding et al. (2007) \\
\hline Myocardin & $\begin{array}{l}\text { S455 } x x x \text { S459 } x x x \\
\text { S463 } x x x \text { S467 } x x x ? \\
\text { S624 } x x x \text { S628 } x x x \\
\text { S632 } x x x \text { S636 } x x x ?\end{array}$ & Development, cardiac hypertrophy & Badorff et al. (2005) \\
\hline Histone H1.5 & $\mathrm{T} 10$ & Chromosome condensation & Happel et al. (2009) \\
\hline $\begin{array}{l}\text { Nascent polypeptide } \\
\text { associated complex }\end{array}$ & T159 & $\begin{array}{l}\text { Transcriptional coactivator, bone } \\
\text { development. }\end{array}$ & Quelo et al. (2004) \\
\hline $\begin{array}{l}\text { Nuclear factor E2-related } \\
\text { factor } 2\end{array}$ & $\ldots ? \ldots$ & Antioxidant response, cell survival & Salazar et al. (2006), Rada et al. (2011) \\
\hline SKN-1 & S393xxxS397 & Oxidative stress, detoxification & An et al. (2005) \\
\hline $\begin{array}{l}\text { Sterol regulatory } \\
\text { element-binding protein }\end{array}$ & T426 $x \times x$ S430 $x \times x ?$ & Lipid and cholesterol metabolism & Sundqvist et al. (2005) \\
\hline MafA/RIPE3 $\beta 1$ & $\ldots ? \ldots$ & $\begin{array}{l}\text { Regulates insulin gene expression in } \beta \text { cells } \\
\text { of pancreas, pancreatic development }\end{array}$ & Han et al. (2007) \\
\hline
\end{tabular}

negative limb of the circadian machinery. PER and CRY proteins are classically thought to translocate into the nucleus to inhibit CLOCK:BMAL1 mediated transcription, thereby closing the negative feedback loop (reviewed in Sahar and Sassone-Corsi, 2009).

GSK-3 is expressed in the primary center of circadian rhythm regulation - the suprachiasmatic nucleus (SCN) of hypothalamus
(Iitaka et al., 2005). GSK-3 $\alpha \mathrm{mRNA}$ is found at higher levels in the mouse SCN than GSK-3 $\beta$ (Iwahana et al., 2004). The expression of both GSK-3 $\alpha$ protein and the phosphorylated form of GSK-3 have a daily rhythm on the SCN, with peak expression of GSK$3 \alpha$ at ZT5 (Iwahana et al., 2004). Lithium treatment reduces the expression of GSK-3 $\alpha$ in the SCN at CT5 and CT 11 (Iwahana et al., 2004). 
Lithium has been shown to lengthen the period of circadian rhythms in a wide range of experimental systems, including unicellular organisms, insects, mice, and humans (Abe et al., 2000; Iwahana et al., 2004; reviewed in Engelmann, 1988). The GSK-3 ortholog in Drosophila, Shaggy (Sgg), plays a central role in determining circadian period length in flies (Martinek et al., 2001). For example, mutation of GSK-3 in Drosophila causes period lengthening (Martinek et al., 2001). Sgg (GSK-3) phosphorylates Timeless and regulates nuclear translocation of the Period/Timeless heterodimer (Martinek et al., 2001).

GSK-3 has also been demonstrated to phosphorylate and regulate the stability of "core" circadian rhythm genes in mammals. GSK-3 together with another serine kinase, DYRK1A, phosphorylates CRY2 at Ser 557 and 553 (respectively) resulting in degradation of CRY2 (Harada et al., 2005; Kurabayashi et al., 2010). GSK-3 phosphorylates BMAL1 (Ser17/Thr21) and these events control the stability of the proteins and the amplitude of circadian oscillation (Sahar et al., 2010). Moreover, GSK-3 has been found to phosphorylate Rev-erb $\alpha$ (Yin et al., 2006), as well as Clock (Spengler et al., 2009). GSK-3 interacts with Per2 in vitro and in vivo, phosphorylates Per2 in vitro and promotes nuclear translocation of Per2 (Iitaka et al., 2005; Kaladchibachi et al., 2007). Overexpression of GSK-3 caused a $\sim 2 \mathrm{~h}$ advance in the phase of mPER2 (Iitaka et al., 2005). Genetic depletion of two alleles of GSK-3 $\beta$ in combination with deletion of one allele of GSK-3 $\alpha$ in synchronized oscillating mouse embryonic fibroblasts
(3/4 GSK-3 $\alpha / \beta$ KO MEFs) resulted in a significant delay in the period of endogenous clock mechanism, particularly in the cycling period of Per 2 (Kaladchibachi et al., 2007). In contrast, one study revealed that siRNA knockdown of GSK-3 $\beta$ or treatment with GSK-3 inhibitors (CHIR 99021 and 1-azakenpaullone) shortened the circadian rhythm (Hirota et al., 2008); however, the same study observed prominent period lengthening by lithium in another experimental system (Hirota et al., 2008). Nevertheless, pharmacological inactivation of GSK-3 by a related molecule (kenpaullone) induced a phase delay in Per2 transcription (Kaladchibachi et al., 2007).

\section{ANIMAL MODELS OF GSK-3}

Several genetic approaches have been used to generate mutant mice for GSK-3: conventional knockouts and knock-ins (all tissues), conditional knockouts (tissue-specific), and transgenic mice (Table 2). Use of mice harboring genetic inactivation or overexpression of one or both of the GSK-3 genes has proven a powerful means to study GSK-3 function in brain development, morphology, neurogenesis, memory and learning, sensorimotor function, sociability, emotionality as well as depressivelike animal behaviors. The listings below are not exhaustive as they focus on publications describing findings relevant to brain functions. There are many more investigating the role of GSK-3 in other tissues (including mammary gland, liver, heart, etc.).

Table 2 | Animal models of GSK-3.

\begin{tabular}{|c|c|c|c|}
\hline Type of approach & Mouse design & Mouse name & Characterized by (reference) \\
\hline \multicolumn{4}{|l|}{ CONVENTIONAL } \\
\hline Knockout & $\begin{array}{l}\text { Deletion of exon } 2 \text { (ATP-binding } \\
\text { loop) of GSK-3 } \alpha\end{array}$ & GSK-3 $\alpha$ KO & $\begin{array}{l}\text { MacAulay et al. (2007), Kaidanovich-Beilin et al. } \\
\text { (2009), Lee et al. (2011), Lipina et al. (2011) }\end{array}$ \\
\hline Knockout & $\begin{array}{l}\text { Deletion of exon } 2 \text { (ATP-binding } \\
\text { loop) of GSK-3 } \beta\end{array}$ & GSK-3 $\beta \mathrm{KO}$ & Hoeflich et al. (2000) \\
\hline Knockout & $\begin{array}{l}\text { Deletion of exon } 2 \text { (ATP-binding } \\
\text { loop) of GSK-3 } \beta\end{array}$ & GSK-3 $\beta$ HET & $\begin{array}{l}\text { Hoeflich et al. (2000), Beaulieu et al. (2004), } \\
\text { O'Brien et al. (2004), Beaulieu et al. (2008), } \\
\text { Bersudsky et al. (2008), Kimura et al. (2008) }\end{array}$ \\
\hline \multicolumn{4}{|l|}{ TRANSGENIC } \\
\hline Knock-in & Mutations GSK-3 $\alpha^{\mathrm{S} 21 \mathrm{~A}}, \beta^{\mathrm{S} 9 \mathrm{~A}}$ & GSK-3 $\alpha, \beta[$ S21A,S9A] KI & $\begin{array}{l}\text { McManus et al. (2005), Eom and Jope (2009), } \\
\text { Ackermann et al. (2010), Mines et al. (2010), } \\
\text { Polter et al. (2010) }\end{array}$ \\
\hline \multicolumn{4}{|l|}{ CONDITIONAL } \\
\hline Double shRNA knockdown & $\begin{array}{l}\text { GSK-3 } \alpha / \beta \text { shRNA } \\
(\text { shGSK-3-dh+/flox }) \times \text { Nestin-Cre }\end{array}$ & Nestin-Cre/shGSK-3-dh+/ ${ }^{+\Delta}$ & Steuber-Buchberger et al. (2008) \\
\hline Conditional knockout & GSK-3 $\alpha /$ GSK-3 $\beta^{\text {flox/flox }} \times$ Nestin-Cre & Nestin-GSK-3 $\alpha+\beta$ KO & Kim et al. (2009) \\
\hline Double shRNA knockdown & GSK-3 $\beta$ shRNA & $\begin{array}{l}\text { DG-GSK-3 } \beta \text { knockdown } \\
\text { (shRNA) }\end{array}$ & Omata et al. (2011) \\
\hline \multicolumn{4}{|l|}{ TRANSGENIC } \\
\hline Dominant-negative (DN) GSK-3 $\beta$ & K85RGSK-3 $\beta \times$ CamkII-tTA-Cre & DN-GSK-3 $\beta$ & Gomez-Sintes et al. (2007) \\
\hline Overexpression of GSK-3 $\beta$ & TetO GSK-3 $\beta \times$ CamkII-tTA-Cre & Tet/GSK-3 $\beta$ & $\begin{array}{l}\text { Lucas et al. (2001), Hernandez et al. (2002), } \\
\text { Engel et al. (2006), Hooper et al. (2007) }\end{array}$ \\
\hline $\begin{array}{l}\text { Overexpression of constitutively } \\
\text { active GSK-3 } \beta \text { [S9A] }\end{array}$ & S9AGSK-3 $\beta$ in Thy- 1 gene vector & GSK-3 $\beta$ [S9A] & $\begin{array}{l}\text { Spittaels et al. (2000), Spittaels et al. (2002), } \\
\text { Prickaerts et al. (2006) }\end{array}$ \\
\hline Overexpression of GSK-3 $\beta$ & $\begin{array}{l}\text { Xenopus GSK-3 } \beta \times \text { mouse prion } \\
\text { promoter MoPrP.Xho }\end{array}$ & $\begin{array}{l}\text { PrpGSK- } 3 \beta^{\mathrm{L} 56} \text { and } \\
\text { PrpGSK-3} \beta^{\mathrm{L} 64}\end{array}$ & O'Brien et al. (2011) \\
\hline
\end{tabular}




\section{CONVENTIONAL KO MICE}

The first GSK-3 gene to be knocked out was GSK-3 $\beta$ (Hoeflich et al., 2000). These animals die late in development either due to hepatic apoptosis (Hoeflich et al., 2000) or a cardiac patterning defect (double outlet, right ventricle; Kerkela et al., 2008).

GSK-3 $\beta$ heterozygous (HET) mice are viable, morphologically normal and have been tested extensively. These animals exhibit a lithium-mimetic, anti-depressant-like state (Beaulieu et al., 2004; O'Brien et al., 2004). Notably, the anti-depressant-like behavior in GSK-3 $\beta$ HET mice effectively normalizes the depressive behavior caused by serotonin deficiency (Beaulieu et al., 2008). Exploratory activity in these animals is reduced although general locomotion remains normal (O'Brien et al., 2004). GSK-3 $\beta$ HET animals show reduced responsiveness to amphetamine treatment (Beaulieu et al., 2004; O’Brien et al., 2004), but have increased morphine-induced locomotion (Urs et al., 2011). Sensorimotor function as well as coordination and balance are normal in GSK$3 \beta$ HET mice (O'Brien et al., 2004; Bersudsky et al., 2008). GSK-3 $\beta$ HET mice demonstrate increased anxiety (Bersudsky et al., 2008) and reduced aggressive behavior (Beaulieu et al., 2008). Recent studies by Kimura et al. (2008) have revealed the importance of GSK-3 $\beta$ in memory reconsolidation in adult brain. Mice heterozygous for GSK-3 $\beta$ exhibit retrograde amnesia (Kimura et al., 2008). These animals have reduced memory reconsolidation but normal memory acquisition, suggesting that they might be impaired in their ability to form long-term memories.

In contrast to GSK-3 $\beta$ null mice, animals lacking GSK-3 $\alpha$ are viable and exhibit improved insulin sensitivity and hepatic glycogen accumulation on the ICR background (MacAulay et al., 2007). However, these anti-diabetic properties are not significant on the C57BL6 background (Patel et al., 2011). Similar to GSK-3ßHET mice (Beaulieu et al., 2004, 2008; O'Brien et al., 2004), GSK-3 $\alpha$ mutants have decreased exploratory activity, decreased immobility time, and anti-aggression behavior (Kaidanovich-Beilin et al., 2009). GSK-3 $\alpha$ KO animals also have abnormal behavioral features that are unique to mice lacking the GSK-3 $\alpha$ gene, such as decreased locomotion, increased sensitivity to environmental cues, decreased social motivation, and novelty; impaired sensorimotor gating, associative memory, and coordination (Kaidanovich-Beilin et al., 2009). GSK-3 $\alpha$ KO mice also exhibit decreased numbers of Purkinje cells in the cerebellum (Kaidanovich-Beilin et al., 2009), as well as decreased dendrite length and surface, but show no changes in spine density in the frontal cortex (Lee et al., 2011).

\section{CONDITIONAL KNOCKDOWN MODELS}

Two studies have employed shRNA knockdown to suppress expression of the two GSK-3 genes in mouse brain. Nestin-Cre was employed to drive shRNA expression in the brain progenitor compartment by excising LoxP flanked transcriptional stop sites. This approach resulted in partial reduction of GSK-3 $\alpha$ and $\beta$ protein levels (60 and 50\%, respectively) in whole brain lysate (SteuberBuchberger et al., 2008). These mice have partial embryonic or neonatal lethality ( $50 \%$ of expected offspring). The surviving double-shGSK-3 $\alpha$ and $\beta$ knockdown animals exhibited $\sim 50 \%$ of the body weight of littermate controls (Steuber-Buchberger et al., 2008).
In an alternative approach, lentivirus-expressing short-hairpin RNAs targeting GSK-3 $\beta$ were injected bilaterally into the hippocampus to inactivate GSK-3 $\beta$ in the dentate gyrus (Omata et al., 2011). These DG-GSK-3 $\beta$ knockdown mice showed decreased immobility time in both forced swim and tail suspension tests (TST), while the locomotor activity of these animals was unchanged (Omata et al., 2011). This technique achieved $30 \%$ suppression of GSK-3 $\beta$ in the hippocampus, sufficient to yield an anti-depressant-like behavior in the mice (Omata et al., 2011).

\section{DOMINANT-NEGATIVE MUTANTS}

Dominant-negatively acting mutants interfere with the endogenous proteins by soaking up downstream targets or upstream regulators. This approach has been used to generate conditional transgenic expression of a dominant-negative (DN) form of GSK$3 \beta$ in the brain (Gomez-Sintes et al., 2007). Mutation of a critical residue involved in ATP-binding, Lys85, to Arg inactivates the protein kinase activity of GSK-3ß (Dominguez et al., 1995). Double transgenic mice were generated that expressed dominant-negative GSK-3 $\beta$ in a tetracycline-repressible manner under control of a promoter that is active in the postnatal forebrain (CamKII $\alpha$ tTA $\times$ K85RGSK-3 $\beta$ ). These DN-GSK-3 $\beta$ mice grew normally and showed no evidence of tumor formation (Gomez-Sintes et al., 2007). However, these animals exhibited increased levels of apoptosis in the brain regions involved in motor control as well as showing behavioral deficits in motor coordination (Gomez-Sintes et al., 2007). Suppression of the DN-GSK3 transgene by doxycycline administration restored normal GSK-3 activity and resulted full reversal of the motor and of the neuronal apoptosis phenotypes (Gomez-Sintes et al., 2007).

\section{OVEREXPRESSION OF GSK-3 $\beta$}

Overexpression of GSK-3 $\beta$ has been postulated to be embryonic lethal as viable transgenic animals show only modest levels of the exogenously engineered gene (Brownlees et al., 1997). Mice overexpressing GSK-3 $\beta$ in the forebrain have been generated by placing the transgene under the control of a tetracycline response element that is induced by administration of doxycycline (Lucas et al., 2001). These Tet/GSK-3 $\beta$ mice have decreased levels of nuclear $\beta$-catenin, increased phosphorylation of tau in Alzheimer's disease-relevant epitopes (correlated with somatodendritic accumulation of microtubule-unbound tau in hippocampal neurons), increased neuronal cell death, and reactive astrocytosis and microgliosis (Lucas et al., 2001). Behavioral characterization of Tet/GSK-3 $\beta$ mice revealed that these animals have impaired acquisition of reference memory in a novel object recognition task (Engel et al., 2006) and impaired spatial learning (Hernandez et al., 2002). Moreover, Tet/GSK-3 $\beta$ mice have reduced LTP induction, a deficit that was rescued by chronic treatment with lithium (Hooper et al., 2007). Thus, mice with conditional overexpression of GSK-3 in forebrain neurons (Tet/GSK-3 $\beta$ ) recapitulate aspects of Alzheimer's disease neuropathology such as tau hyperphosphorylation, apoptotic neuronal death, and reactive astrocytosis, as well as spatial learning deficits. Moreover, these sequelae can be completely reverted by restoration of GSK-3 activity by silencing of transgene expression indicating that these biological defects, at 
least, may be responsive to therapeutic intervention (Engel et al., 2006).

Transgenic mice have also been generated that overexpress a mutant form of GSK-3 $\beta$ in which the inhibitory N-terminal phosphorylation site is mutated [S9A] (Spittaels et al., 2000, 2002). This form of the kinase cannot be inhibited by agonists of pathways that promote phosphorylation of this site (such as PI3K, cAMP, etc.). These mice are characterized by microcephaly and higher neuronal density due to reduction of the volume of the somatodendritic compartment (dendrites and cell bodies) of pyramidal neurons in the cortex (Spittaels et al., 2002). The levels of MAP2 were also significantly decreased in the brain and spinal cord of GSK-3 $\beta$ [S9A] mice (Spittaels et al., 2002). However, postnatal overexpression of this non-inhibitable form of GSK-3 $\beta$ in neurons did not alter behaviors of the mice in terms of general cognition and aging and they showed only a minor decline in psychomotor capability (Spittaels et al., 2002). Subsequent characterization revealed that mice with constitutive overexpression of GSK-3 $\beta$ [S9A] showed hypophagia, reduced water consumption, increased general locomotor activity, and increased ASR (acoustic startle response; Prickaerts et al., 2006). GSK-3 [S9A] mice showed reduced immobility times in the forced swim test (FST) but this is likely related to the hyperactivity of these animals (Prickaerts et al., 2006). There were no differences in baseline and stress-induced increases of plasma adrenocorticotrophic hormone and corticosterone levels in GSK$3 \beta$ [S9A] mice (Prickaerts et al., 2006). Biochemical examination in these animals revealed upregulation of Akt1 together with downregulation of PPP2R3A (regulatory subunit of PP2A) and GSK-3 $\alpha$ in the striatum, as well as increased brain-derived neurotrophic factor (BDNF) in the hippocampus (Prickaerts et al., 2006). In summary, mice overexpressing active GSK-3 $\beta[\mathrm{S} 9 \mathrm{~A}]$ represent a model for studying hyperactivity, hyperreactivity, and disturbed eating patterns; aspects which recapitulate some of the symptoms observed in the manic phase of bipolar disorder patients, ADHD, and schizophrenia.

\section{GSK-3 $\alpha, \beta$ MUTANT KNOCK-IN MICE}

As mentioned above, mutation of the N-terminal phosphorylation sites of GSK-3 renders the protein kinase insensitive to inhibition by that mode of regulation (although the kinase remains sensitive to Wnt regulation, for example). Mice have been generated in which the phosphorylation sites of the endogenous alleles have been replaced by non-phosphorylatable alanine (GSK- $\alpha$ S21A, $\beta S 9 A)$. Since serine phosphorylation of GSK-3 is increased by lithium, anti-psychotic drugs, anti-depressants, etc., this model is attractive to use for studying the mechanism of action of aforementioned drugs and related pathological conditions. GSK- $\alpha$ S21A, $\beta S 9 \mathrm{~A}$ knock-in mice have normal development and growth, with no signs of metabolic abnormalities/insulin resistance (McManus et al., 2005). However, these animals have a drastic (40\%) impairment in neurogenesis, which is not increased/rescued by co-administration of fluoxetine and lithium (Eom and Jope, 2009). Expression of vascular endothelial growth factor (VEGF), but not BDNF, was reduced in GSK- $\alpha$ S21A, $\beta S 9 A$ knock-in mice, suggesting that a deficiency in external support for neural precursor cells might contribute to impaired neurogenesis (Eom and Jope, 2009).
GSK- $\alpha$ S21A, $\beta$ S9A knock-in mice exhibited increased susceptibility to hyperactivity and a heightened response to a novel environment (Polter et al., 2010). Moreover, these animals revealed increased susceptibility to amphetamine-induced hyperactivity, which was partially reversed by chronic lithium administration (Polter et al., 2010). Besides being sensitive to hyperactivity, these knock-in mutant mice displayed mild anxiety, had increased immobility time in FST and TST and were highly susceptible to stress-induced depressive-like behavior (Polter et al., 2010). In contrast, studies by another group revealed decreased immobility time in FST, indicating a phenotype less prone to depression (Ackermann et al., 2010). LTD in the mutants was found to be abnormal and emotion-associated memory was impaired (Polter et al., 2010). The knock-in animals also demonstrated impaired social preference (Mines et al., 2010). Additional studies revealed increased curiosity in these animals, associated with less sensitivity to application of chronic mild stress as well as decreased HPA axis activity (Ackermann et al., 2010).

\section{CONDITIONAL KNOCKOUT MOUSE MODELS}

Alleles of GSK- $3 \alpha$ and $\beta$ have been generated in which exon 2 (containing essential residues for ATP-binding) are flanked by LoxP (flox) sites (Figure 1). Tissue-specific expression of Cre recombinase allows selective excision of the critical exon and inactivation of the allele(s). Combination of a floxed GSK- $3 \beta$ gene on a GSK$3 \alpha$ null background has been employed to generate total GSK-3 nullizygous cells in the developing nervous system via nestin-Cre mediated excision (Nestin-GSK-3 $\alpha, \beta$ KO; Kim et al., 2009). Selective deletion of both GSK-3 $\alpha$ and $\beta$ in neural precursor cells results in dramatic hyperproliferation of neuronal progenitors along the entire rostrocaudal extent of the neuraxis. The progenitor expansion was at the expense of neurogenesis, intermediate neural progenitors, and post-mitotic neurons indicating effective inhibition of the differentiation process (Kim et al., 2009). The morphological abnormalities were accompanied by dysregulation of $\beta$-catenin, Hedgehog and Notch signaling as well as loss of polarity of cell division (Kim et al., 2009).

\section{LESSONS LEARNED FROM COMPARING BETWEEN GSK-3 ANIMAL MODELS}

Ten different GSK-3 animal models have been described to date (Table 2). All of them display some kind of neuroanatomical and behavioral abnormalities (Tables 3-6). However some of them have not been fully characterized yet and require further examinations. Overall, analysis of different animal models supports in vivo role of GSK-3 in the regulation of fundamental brain functions (emotionality, sociability, learning and memory, and neurogenesis, etc.).

The differences in behavioral results between different GSK3 animal models may be accounted for by the alternative design of the models, and/or by strain and gender differences, varying methodology, and animal house-keeping environment.

Well described and presented is effect of genetic GSK-3 manipulations on depressive-like phenotype in mice (Table 3). In all three models, inactivation of GSK-3 $\alpha$ or $\beta$ genes (Table 3 ) revealed anti-depressive phenotypes, supporting studies with GSK-3 inhibitors. However, a similar effect was found in mice 
Table 3 | Emotionality behaviors of GSK-3 mutant mice.

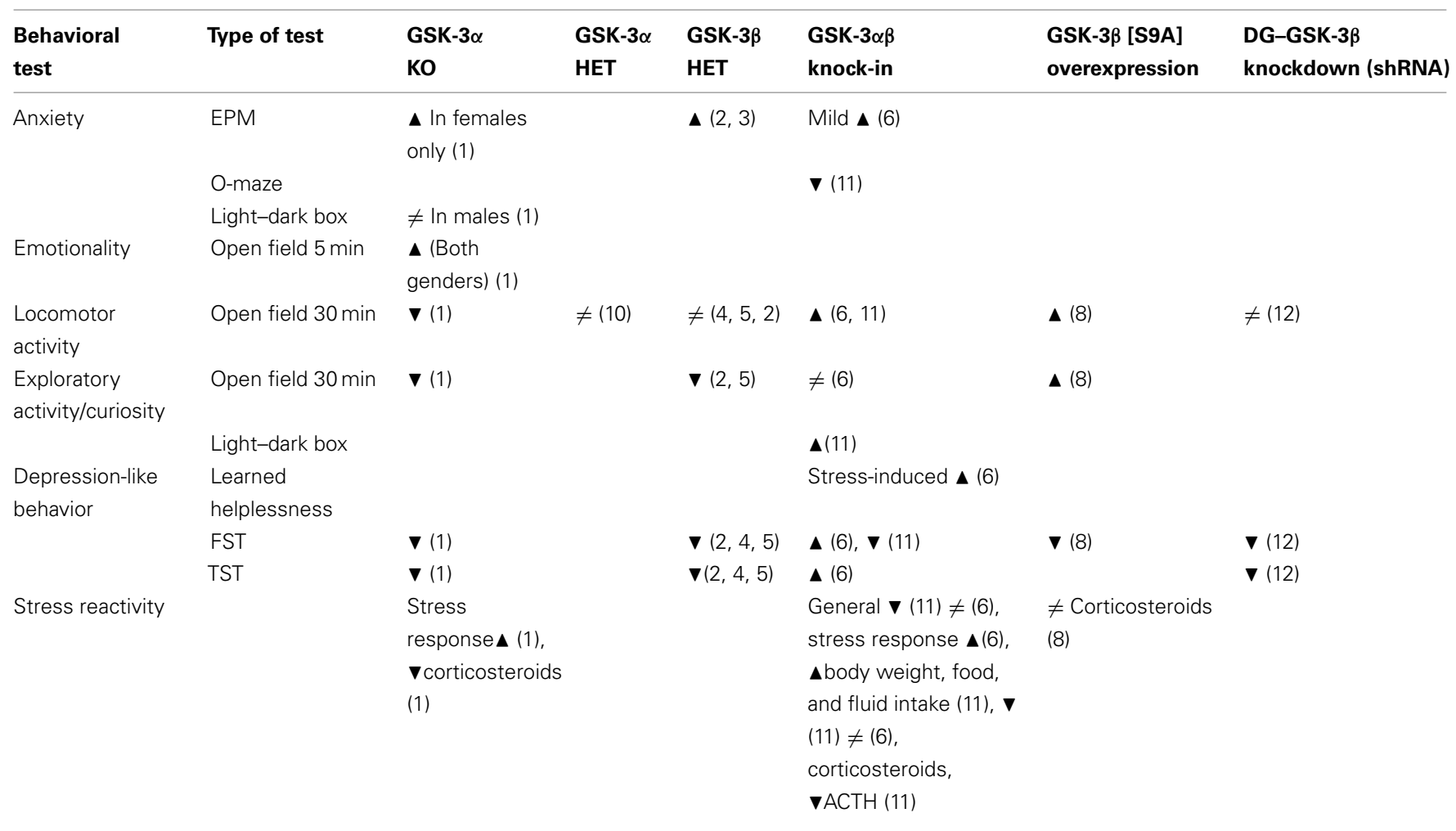

$\boldsymbol{\Lambda}$, Increased; $\mathbf{\nabla}$, decreased; $\neq$, same/no changes.

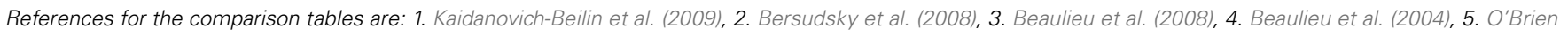
et al. (2004), 6. Polter et al. (2010), 8. Prickaerts et al. (2006), 10. Lipina et al. (2011), 11. Ackermann et al. (2010), 12. Omata et al. (2011).

Table 4 | Sociability behaviors of GSK-3 mutant mice.

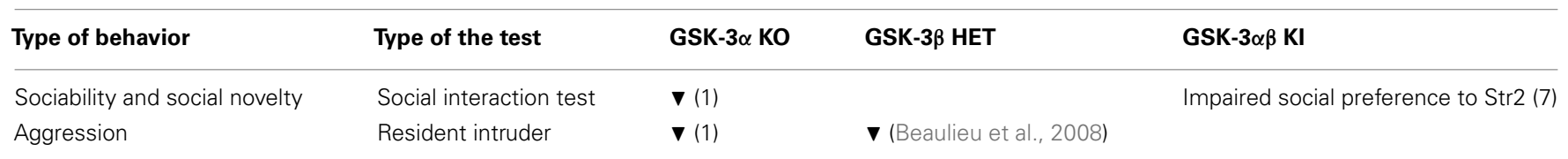

\section{v, Decreased.}

References for the comparison tables are: 1. Kaidanovich-Beilin et al. (2009), 7. Mines et al. (2010).

overexpressing GSK-3 $\beta$ (GSK-3 $\beta$ S9A mice; Table 3). The contradictory result in GSK-3 $\beta$ S9A mice was explained by increased locomotor activity in these animals, which may affect performance in the FST and its interpretation.

It is important to mention that different GSK-3 animal models have employed different "Cre" promoters. Activation of specific "Cre" recombinases may happen at different stages of embryogenesis (or after birth), thus may affect specific neuronal populations (post-mitotic or precursors), which may affect structure and function of adult brain. For example, dominant-negative GSK-3 $\beta$ and Tet/GSK-3 $\beta$ mice have been generated by using CamkII $\alpha$-Cre, compare to GSK-3 $\beta$ S9A mice which have been created by using Thy-1 gene promoter (Table 2 ).

Moreover, there are different approaches have been used to generate mice with overexpression of GSK- $3 \beta$ gene. In all three models with overexpression of GSK-3 $\beta$, different constructs for GSK-3 $\beta$ gene itself were used (Table 2): intact GSK-3 $\beta$ in Tet/GSK-3 $\beta$ mice versus point mutated form of GSK-3 $\beta$ (S9A) in GSK-3 3 [S9A] animals. GSK-3 has complex mechanisms of regulation, thus, is it likely that overexpression of wild type protein has different effects on specific brain functions than Serine 9 mutated forms of the protein, depending on the relative importance of "phosphorylation" as the regulatory mechanism in specific brain process/stimulation and structure.

Comparison between GSK-3 $\alpha$ KO and GSK- $3 \alpha+\beta$ serine phosphorylation site KI mice revealed similar impaired sociability in both models, despite different genetic approaches being used. These data indicate that both the protein level of GSK-3 $\alpha$ as well as serine phosphorylation of GSK-3 are important aspects for neuronal circuits responsible for social interaction.

Moreover, studying and analyzing genetic animal models may be used to make predictions about long-term usage of GSK-3 
Table 5 | Memory, informational process, pharmacology, coordination behaviors of GSK-3 mutant mice.

\begin{tabular}{|c|c|c|c|c|c|c|c|c|}
\hline $\begin{array}{l}\text { Type of } \\
\text { behavior }\end{array}$ & $\begin{array}{l}\text { Type of } \\
\text { the test }\end{array}$ & $\begin{array}{l}\text { GSK-3 } \alpha \\
\text { KO }\end{array}$ & $\begin{array}{l}\text { GSK-3 } \alpha \\
\text { HET }\end{array}$ & $\begin{array}{l}\text { GSK-3 } \beta \\
\text { HET }\end{array}$ & $\begin{array}{l}\text { GSK-3 } \alpha \beta \\
\text { KI }\end{array}$ & $\begin{array}{l}\text { GSK-3 } \beta \text { [S9A] } \\
\text { overexpression }\end{array}$ & $\begin{array}{l}\text { Tet/GSK- } \\
3 \beta\end{array}$ & $\begin{array}{l}\text { DN- } \\
\text { GSK-3 } \beta\end{array}$ \\
\hline $\begin{array}{l}\text { Amphetamine } \\
\text { response }\end{array}$ & $\mathrm{OF}+\mathrm{amp}$ & $\Delta$ & & $\nabla(4)$ & $\Delta(6)$ & & & $\boldsymbol{\nabla}(16)$ \\
\hline $\begin{array}{l}\text { Response to } \\
\text { morphine }\end{array}$ & OF + morph & & & $\boldsymbol{\Delta}(23)$ & & & & \\
\hline \multirow{2}{*}{$\begin{array}{l}\text { Information } \\
\text { processing }\end{array}$} & PPI/ASR & $\Delta \mathrm{PPI}(1)$ & $\neq(10)$ & $\neq(2,5)$ & & $\Delta \mathrm{ASR}(8)$ & & \\
\hline & $\mathrm{LI}$ & $\begin{array}{l}\triangle \mathrm{NPE} \text { in } \mathrm{KO} \\
(1)\end{array}$ & $\neq(10)$ & & & & & \\
\hline \multirow{6}{*}{$\begin{array}{l}\text { Long-term } \\
\text { memory }\end{array}$} & $\mathrm{FC}$ & $\boldsymbol{\nabla}(1)$ & & Impaired & $\boldsymbol{\Delta}(6)$, Enhanced & & & \\
\hline & & & & memory & emotion- & & & \\
\hline & & & & reconsolidation & associated & & & \\
\hline & & & & (9) & memory & & & \\
\hline & Passive avoidance & $\neq(1)$ & & & & & & \\
\hline & LTP/LTD & & & & $\begin{array}{l}\text { abnormal LTD in } \\
\text { the ventral } \\
\text { hippocampus (6) }\end{array}$ & & $\boldsymbol{\nabla}(20)$ & \\
\hline Spatial memory & & & & & & & Impaired (22) & \\
\hline $\begin{array}{l}\text { Coordination, } \\
\text { balance }\end{array}$ & Rotarod & $\boldsymbol{\nabla}(1)$ & & $\neq(2,5)$ & & & & $\boldsymbol{\nabla}(16)$ \\
\hline Motor learning & Rotarod & $\neq(1)$ & & $\neq(2,5)$ & & & & \\
\hline
\end{tabular}

$\boldsymbol{\Lambda}$, Increased; $\mathbf{\nabla}$, decreased; $\neq$, same/no changes.

References for the comparison tables are: 1. Kaidanovich-Beilin et al. (2009), 2. Bersudsky et al. (2008), 4. Beaulieu et al. (2004), 5. O'Brien et al. (2004), 6. Polter et al. (2010), 8. Prickaerts et al. (2006), 9. Kimura et al. (2008), 10. Lipina et al. (2011), 16. Gomez-Sintes et al. (2007), 20. Hooper et al. (2007), 22. Hernandez et al. (2002).

inhibitors (as therapeutic agents). For example, the well characterized GSK-3 inhibitor - lithium - has a diverse spectrum of effects after long-term treatment of patients, including tremor and death of Purkinje cells. Of note, similar changes in cerebellar structure and function were observed in GSK-3 $\alpha \mathrm{KO}$ and dominant-negative GSK-3 $\beta$ mice (Tables 5 and $\mathbf{6}$ ).

Thus, comparative analysis of different animal models may be very informative, however critical and combinatory approach needs to be used to make correct interpretation and right conclusions.

\section{PATHOGENESIS OF NEUROLOGICAL DISORDERS THOUGH CROSSBREEDING OF GSK-3 MUTANT MICE AND OTHER NEUROLOGICAL MUTANTS}

To study the role of GSK-3 $\beta$ in the pathogenesis of Alzheimer's disease, particularly with respect to the mechanism of tauopathy, double transgenic mice have been generated by inter-breeding mice overexpressing GSK-3 $\beta$ [S9A] with transgenic mice that overexpress the longest isoform of human protein tau (Spittaels et al., 1999, 2000). Biochemical examination of brain and spinal cord extracts from double transgenic mice revealed that the amount of protein tau associated with microtubules was reduced compared to mice harboring only hTau40 (Spittaels et al., 2000). Moreover, unbound tau protein was hyperphosphorylated suggesting that additional phosphorylation of tau in the double transgenic mice reduces its binding capacity to microtubules, but fails to cause tau filament formation (Spittaels et al., 2000). Importantly, virtually all of the pathological defects observed in the hTau40 transgenic mice (Spittaels et al., 1999) were rescued by the mild overexpression of GSK-3 $\beta$, such as the reduction by about an order of magnitude of the number of axonal dilations in the brain and spinal cord, the reduction in axonal degeneration and muscular atrophy, as well as the alleviation of most motoric complication (Spittaels et al., 2000).

DISC1 (Disrupted-in-Schizophrenia-1) is one of the best characterized genetic risk factors for schizophrenia (reviewed in Harrison and Weinberger, 2005; Chubb et al., 2008; Brandon et al., 2009; Jaaro-Peled et al., 2009). One breakpoint of a chromosomal $t(1 ; 11)$ (q42.1;q14.3) translocation has been identified within DISC1 gene, which co-segregates in a Scottish family with major mental illness, including schizophrenia, bipolar disorder, and major depression (Millar et al., 2000; Blackwood et al., 2001). DISC1 has been demonstrated to play a role in essential brain functions from embryonic development through to adulthood (reviewed in JaaroPeled et al., 2009), such as neurogenesis, neuronal migration, neurite outgrowth, spine development, neurotransmitter signaling, cytoskeletal organization, cell cycle, signal transduction, intracellular transport/exocytosis, etc.(reviewed in Chubb et al., 2008; Brandon et al., 2009; Jaaro-Peled et al., 2009). DISC1 appears to act as a coordinating hub or scaffold protein and has multiple intracellular interacting proteins including GSK-3 (Camargo et al., 2007; Mao et al., 2009; Lipina et al., 2011).

GSK-3 acts as an important downstream component in the etiology of schizophrenia (reviewed in more detail elsewhere in this 
Table 6 | Neurogenesis, anatomical changes, biochemical, histological, and molecular characterizations of GSK-3 mutant mice.

\begin{tabular}{|c|c|c|c|c|c|c|c|}
\hline $\begin{array}{l}\text { Type of } \\
\text { analysis }\end{array}$ & Type of test & GSK-3 $\alpha$ KO & Tet/GSK-3 $\beta$ & GSK- $3 \alpha \beta$ KI & $\begin{array}{l}\text { GSK-3B [S9A] } \\
\text { overexpression }\end{array}$ & $\begin{array}{l}\text { Nestin-GSK- } \\
3 \alpha \beta \text { KO }\end{array}$ & DN-GSK-3ß \\
\hline $\begin{array}{l}\text { Neuro } \\
\text { genesis }\end{array}$ & $\begin{array}{l}\text { BrdU }[3 \mathrm{H}] \\
\text { thymidine } \\
\text { incorporation }\end{array}$ & & & $\begin{array}{l}\boldsymbol{\nabla} \\
\text { Proliferation } \\
\text { (14) }\end{array}$ & $\neq$ Proliferation (8) & $\begin{array}{l}\Delta \text { Proliferation } \\
\text { (15), } \boldsymbol{\nabla} \text { differ- } \\
\text { entiation (15) }\end{array}$ & \\
\hline $\begin{array}{l}\text { Apoptosis } \\
\text { necrosis }\end{array}$ & $\begin{array}{l}\text { TUNEL, } \\
\text { caspase IHC }\end{array}$ & & $\begin{array}{l}\text { A } \\
\text { Apoptosis } \\
\text { (17) }\end{array}$ & $\begin{array}{l}\neq \\
\text { Apoptosis } \\
(14)\end{array}$ & $\begin{array}{l}\neq \text { Apoptosis }(18), \neq \\
\text { necrosis }(18)\end{array}$ & & $\begin{array}{l}\Delta \text { Apoptosis } \\
(16)\end{array}$ \\
\hline \multirow[t]{3}{*}{$\begin{array}{l}\text { Neuro } \\
\text { anatomical } \\
\text { changes }\end{array}$} & MRI & $\begin{array}{l}\Delta \text { Cerebellum } \\
\text { (1) }\end{array}$ & & & $\begin{array}{l}\text { V Cerebellum, } \\
\text { cerebrum, } \\
\text { hippocampus, cortex } \\
\text { (18) }\end{array}$ & & \\
\hline & Histology & 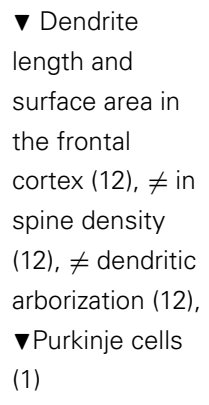 & $\begin{array}{l}\Delta \\
\text { Microgliosis } \\
\text { (17), } \neq \text { tau } \\
\text { fibrils (17, } \\
22 \text { ) }\end{array}$ & & $\begin{array}{l}\text { N Neuronal density in } \\
\text { cortex (18), } \neq \text { number } \\
\text { of cortical neurons (18), } \\
\mathbf{v} \text { caliber of the } \\
\text { proximal and distal part } \\
\text { of the apical dendrites } \\
\text { (18), } \mathbf{\nabla} \text { size of the cell } \\
\text { body of pyramidal } \\
\text { neurons (18) }\end{array}$ & $\begin{array}{l}\boldsymbol{\nabla} \text { Tuj1, MAP2, } \\
\text { SMI32, NeuN } \\
\text { (15), \ Nestin, } \\
\text { Pax6 (15) }\end{array}$ & \\
\hline & Brain weight & $\Delta$ Brain (1) & & & $\begin{array}{l}\text { V Brain and spinal cord } \\
(18,8)\end{array}$ & & \\
\hline $\begin{array}{l}\text { Biochemical } \\
\text { molecular }\end{array}$ & $\begin{array}{l}\text { Western blot } \\
\text { RTPCR }\end{array}$ & & $\begin{array}{l}\boldsymbol{\Delta} \text { pTau (17), } \\
\boldsymbol{\nabla} \text { nuclear } \\
\beta \text {-catenin } \\
(17)\end{array}$ & $\begin{array}{l}\boldsymbol{\nabla} \text { VEGF } \\
(14), \neq \\
\text { BDNF (14) }\end{array}$ & 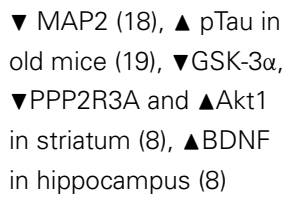 & $\begin{array}{l}\Delta \beta \text {-catenin, Axin, } \\
\text { c-jun, Gli1, Gli2, } \\
\text { Patched, Hes1, } \\
\text { Hes5, NICD, } \\
\text { c-myc, N-myc (15) }\end{array}$ & $\begin{array}{l}\boldsymbol{\nabla} \text { pTau }(16), \neq \\
\beta \text {-catenin (16) }\end{array}$ \\
\hline
\end{tabular}

$\boldsymbol{\Lambda}$, Increased; $\mathbf{\nabla}$, decreased; $\neq$, same/no changes.

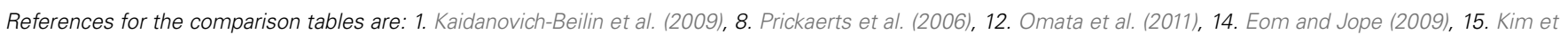
al. (2009), 16. Gomez-Sintes et al. (2007), 17. Lucas et al. (2001), 18. Spittaels et al. (2002), 19. Spittaels et al. (2000), 22. Hernandez et al. (2002).

Special Topic series). There are several lines of evidence supporting the involvement of GSK-3 in the pathogenesis of schizophrenia. Polymorphisms in GSK-3 genes have been associated with schizophrenia (Souza et al., 2008; Benedetti et al., 2010). Dysregulation of the PKB/Akt/GSK-3 signaling pathway has been found in subjects with schizophrenia (reviewed in Koros and DornerCiossek, 2007; Lovestone et al., 2007; Beaulieu et al., 2009; Freyberg et al., 2009). For example, phosphorylation of GSK-3 $\beta$ Ser9 is reduced in the peripheral lymphocytes and brains of schizophrenia patients (Emamian et al., 2004). Drugs that influence the DA and 5-HT systems indirectly affect the activity of GSK3 (this topic is reviewed in greater detail in another chapter in this Special Topic series). In the dopaminergic system, antipsychotic, and psychotomimetic drugs alter GSK-3 function (Mai et al., 2002; Svenningsson et al., 2003; Beaulieu et al., 2004; Emamian et al., 2004; Li et al., 2007). Lithium is used to augment anti-psychotic treatment in schizophrenia patients (Kang et al., 2004; Gould, 2006). Moreover, GSK-3 inhibitors can rescue schizophrenia-like behaviors in mice (Beaulieu et al., 2004; Lipina et al., 2011).
Several mouse models for Disc1 have been described (reviewed in Jaaro-Peled et al., 2009). For example, overexpression of the N-terminal portion of Discl in the dentate gyrus causes interaction with GSK-3, suppressing activity, and perturbing ability to down-regulate the $\mathrm{Wnt} / \beta$-catenin pathway resulting in proliferation of neuronal progenitors (Mao et al., 2009). Treatment with a GSK-3 inhibitor, SB216763 rescued the behavioral effects of lentivirally induced DISC1 suppression in the adult dentate gyrus (Mao et al., 2009).

An ENU-induced mutant of Disc1, Disc1-L100P, exhibits schizophrenia-related behaviors in mice (Clapcote et al., 2007). Pharmacological as well as genetic inactivation of one allele of GSK-3 $\alpha$ reverses pre-pulse inhibition (PPI) and latent inhibition (LI) deficits as well as normalizing the hyperactivity of Disc1L100P mutants (Lipina et al., 2011). In parallel to these observations, interaction between DISC1 and GSK-3 $\alpha$ and $\beta$ is reduced in Disc1-L100P mutants (Lipina et al., 2011). At the histological level, genetic inactivation of GSK-3 $\alpha$ partially corrected neurite outgrowth and spine development abnormalities in the frontal cortex induced by the Disc1-L100p mutation (Lee et al., 2011). 


\section{SUMMARY}

The emergence of sophisticated animal models with tissue and developmentally selective expression of GSK-3 has allowed direct assessment of the roles of this protein kinase in a variety of neurological processes and conditions. Clearly, the complexity of brain development and disease pathogenesis requires the use of animal models to examine the biological role of candidate components and with the numbers of candidate genes for neurological illness increasing, allows relatively rapid assessment of genetic interactions through inter-breeding of variant alleles.

While GSK-3 was first implicated in a neurological disorder in 1992 through its capacity to phosphorylate residues on Tau that are associated with neurofibrillary tangles in $\mathrm{AD}$, the potential importance of this kinase in brain function and disease took off with the identification by Klein and Melton of GSK-3 as a direct target of lithium (Klein and Melton, 1996; Stambolic et al., 1996). Since that time, there has been enormous expansion of understanding of this protein kinase with respect to regulation, roles in normal development, and in pathophysiology. However, despite this tsunami of knowledge, there are many remaining questions including the therapeutic reality of modulating GSK3 in these disorders. Since the beneficial effects of lithium on stabilization of bipolar disorder is achieved at serum levels that reduce GSK-3 levels by only 25\% (noting that there are likely several other targets of this drug) and the behavioral phenotypes of Disc1L110P mutations are alleviated by knocking out only one allele of GSK-3 $\alpha$ (Lipina et al., 2011), subtle drug modulation of GSK-3 may be sufficient for therapeutic benefit in humans.

\section{ACKNOWLEDGMENTS}

We thank members of the Woodgett lab (especially Charles Burger) for helpful discussions as well as Frankie Lee, Albert Wong, Tatiana Lipina, and John Roder. James Robert Woodgett is supported by an operating grant from the Canadian Institutes of Health Research (MOP74711).

\section{REFERENCES}

Abe, M., Herzog, E. D., and Block, G. D. (2000). Lithium lengthens the circadian period of individual suprachiasmatic nucleus neurons. Neuroreport 11, 3261-3264.

Aberle, H., Bauer, A., Stappert, J., Kispert, A., and Kemler, R. (1997). Beta-catenin is a target for the ubiquitin-proteasome pathway. EMBO J. 16, 3797-3804.

Ackermann, T. F., Kempe, D. S., Lang, F., and Lang, U. E. (2010). Hyperactivity and enhanced curiosity of mice expressing PKB/SGKresistant glycogen synthase kinase-3 (GSK-3). Cell. Physiol. Biochem. 25, 775-786.

Aitken, A., Holmes, C. F., Campbell, D. G., Resink, T. J., Cohen, P., Leung, C. T., and Williams, D. H. (1984). Amino acid sequence at the site on protein phosphatase inhibitor2, phosphorylated by glycogen synthase kinase-3. Biochim. Biophys. Acta 790, 288-291.

Alabed, Y. Z., Pool, M., Ong Tone, S., Sutherland, C., and Fournier, A. E. (2010). GSK3 beta regulates myelindependent axon outgrowth inhibition through CRMP4. J. Neurosci. 30, 5635-5643.

Alessi, D. R., Andjelkovic, M., Caudwell, B., Cron, P., Morrice, N., Cohen, P., and Hemmings, B. A. (1996). Mechanism of activation of protein kinase $\mathrm{B}$ by insulin and IGF-1. EMBO J. 15, 6541-6551.

Ali, A., Hoeflich, K. P., and Woodgett, J. R. (2001). Glycogen synthase kinase-3: properties, functions, and regulation. Chem. Rev. 101, 2527-2540.

Al-Khouri, A. M., Ma, Y., Togo, S. H., Williams, S., and Mustelin, T. (2005).
Cooperative phosphorylation of the tumor suppressor phosphatase and tensin homologue (PTEN) by casein kinases and glycogen synthase kinase 3beta. J. Biol. Chem. 280, 35195-35202.

Alon, L. T., Pietrokovski, S., Barkan, S., Avrahami, L., Kaidanovich-Beilin, O., Woodgett, J. R., Barnea, A., and Eldar-Finkelman, H. (2011). Selective loss of glycogen synthase kinase-3alpha in birds reveals distinct roles for GSK-3 isozymes in tau phosphorylation. FEBS Lett. 585, 1158-1162.

Amit, S., Hatzubai, A., Birman, Y., Andersen, J. S., Ben-Shushan, E., Mann, M., Ben-Neriah, Y., and Alkalay, I. (2002). Axin-mediated CKI phosphorylation of beta-catenin at Ser 45: a molecular switch for the Wnt pathway. Genes Dev. 16, 1066-1076.

An, J. H., Vranas, K., Lucke, M., Inoue, H., Hisamoto, N., Matsumoto, K., and Blackwell, T. K. (2005). Regulation of the Caenorhabditis elegans oxidative stress defense protein SKN-1 by glycogen synthase kinase3. Proc. Natl. Acad. Sci. U.S.A. 102, 16275-16280.

Aplin, A. E., Gibb, G. M., Jacobsen, J. S., Gallo, J. M., and Anderton, B. H. (1996). In vitro phosphorylation of the cytoplasmic domain of the amyloid precursor protein by glycogen synthase kinase-3beta. J. Neurochem. 67, 699-707.

Armstrong, J. L., Bonavaud, S. M., Toole, B. J., and Yeaman, S. J. (2001). Regulation of glycogen synthesis by amino acids in cultured human muscle cells. J. Biol. Chem. 276, 952-956.
Azoulay-Alfaguter, I., Yaffe, Y., LichtMurava, A., Urbanska, M., Jaworski, J., Pietrokovski, S., Hirschberg, K., and Eldar-Finkelman, H. (2011). Distinct molecular regulation of glycogen synthase kinase-3alpha isozyme controlled by its $\mathrm{N}$-terminal region: functional role in calcium/calpain signaling. J. Biol. Chem. 286, 13470-13480.

Badorff, C., Seeger, F. H., Zeiher, A. M., and Dimmeler, S. (2005). Glycogen synthase kinase 3beta inhibits myocardin-dependent transcription and hypertrophy induction through site-specific phosphorylation. Circ Res. 97, 645-654.

Bain, J., Plater, L., Elliott, M., Shpiro, N., Hastie, C. J., McLauchlan, H., Klevernic, I., Arthur, J. S., Alessi, D. R., and Cohen, P. (2007). The selectivity of protein kinase inhibitors: a further update. Biochem. J. 408, 297-315.

Ballou, L. M., Tian, P. Y., Lin, H. Y., Jiang, Y. P., and Lin, R. Z. (2001). Dual regulation of glycogen synthase kinase-3beta by the alpha1Aadrenergic receptor. J. Biol. Chem. 276, 40910-40916.

Bax, B., Carter, P. S., Lewis, C., Guy, A. R., Bridges, A., Tanner, R., Pettman, G., Mannix, C., Culbert, A. A., Brown, M. J., Smith, D. G., and Reith, A. D. (2001). The structure of phosphorylated GSK3beta complexed with a peptide, FRATtide, that inhibits beta-catenin phosphorylation. Structure 9, 1143-1152.

Beals, C. R., Sheridan, C. M., Turck, C. W., Gardner, P., Crabtree, G. R. (1997). Nuclear export of NFATc enhanced by glycogen synthase kinase-3. Science 275, 1930-1934.
Beaulieu, J. M., Gainetdinov, R. R., and Caron, M. G. (2009). Akt/GSK3 signaling in the action of psychotropic drugs. Annu. Rev. Pharmacol. Toxicol. 49, 327-347.

Beaulieu, J. M., Sotnikova, T. D., Yao, W. D., Kockeritz, L., Woodgett, J. R., Gainetdinov, R. R., and Caron, M. G. (2004). Lithium antagonizes dopamine-dependent behaviors mediated by an AKT/glycogen synthase kinase 3 signaling cascade. Proc. Natl. Acad. Sci. U.S.A. 101, 5099-5104.

Beaulieu, J. M., Zhang, X., Rodriguiz, R. M., Sotnikova, T. D., Cools, M. J., Wetsel, W. C., Gainetdinov, R R., and Caron, M. G. (2008). Role of GSK3 beta in behavioral abnormalities induced by serotonin deficiency. Proc. Natl. Acad. Sci. U.S.A. 105, 1333-1338.

Benchabane, H., Hughes, E. G., Takacs, C. M., Baird, J. R., and Ahmed Y. (2008). Adenomatous polyposis coli is present near the minimal level required for accurate graded responses to the Wingless morphogen. Development 135, 963-971.

Benedetti, F., Poletti, S., Radaelli, D., Bernasconi, A., Cavallaro, R., Falini, A., Lorenzi, C., Pirovano, A., Dallaspezia, S., Locatelli, C., Scotti, G., and Smeraldi, E. (2010). Temporal lobe grey matter volume in schizophrenia is associated with a genetic polymorphism influencing glycogen synthase kinase 3-beta activity. Genes Brain Behav. 9, 365-371.

Benjamin, W. B., Pentyala, S. N., Woodgett, J. R., Hod, Y., and Marshak, D. (1994). ATP citrate-lyase and glycogen synthase kinase-3 beta in 3T3L1 cells during differentiation into 
adipocytes. Biochem. J. 300(Pt 2), 477-482.

Bersudsky, Y., Shaldubina, A., Kozlovsky, N., Woodgett, J. R., Agam, G., and Belmaker, R. H. (2008). Glycogen synthase kinase-3beta heterozygote knockout mice as a model of findings in postmortem schizophrenia brain or as a model of behaviors mimicking lithium action: negative results. Behav Pharmacol 19, 217-224.

Bianchi, M., De Lucchini, S., Marin, O., Turner, D. L., Hanks, S. K., and Villa-Moruzzi, E. (2005). Regulation of FAK Ser-722 phosphorylation and kinase activity by GSK3 and PP1 during cell spreading and migration. Biochem. J. 391( $\mathrm{Pt} \mathrm{2}$ ), 359-370.

Bijur, G. N., and Jope, R. S. (2001). Proapoptotic stimuli induce nuclear accumulation of glycogen synthase kinase-3 beta. J. Biol. Chem. 276, 37436-37442.

Bijur, G. N., and Jope, R. S. (2003). Glycogen synthase kinase-3 beta is highly activated in nuclei and mitochondria. Neuroreport 14, 2415-2419.

Blackwood, D. H., Fordyce, A., Walker, M. T., St Clair, D. M., Porteous, D. J., and Muir, W. J. (2001). Schizophrenia and affective disorders - cosegregation with a translocation at chromosome 1q42 that directly disrupts brain-expressed genes: clinical and P300 findings in a family. Am. J. Hum. Genet. 69, 428-433.

Boyle, W. J., Smeal, T., Defize, L. H., Angel, P., Woodgett, J. R., Karin, M., and Hunter, T. (1991). Activation of protein kinase $\mathrm{C}$ decreases phosphorylation of c-Jun at sites that negatively regulate its DNA-binding activity. Cell 64, 573-584.

Brady, M. J., Bourbonais, F. J., and Saltiel, A. R. (1998). The activation of glycogen synthase by insulin switches from kinase inhibition to phosphatase activation during adipogenesis in 3T3-L1 cells. J. Biol. Chem. 273, 14063-14066.

Brandon, N. J., Millar, J. K., Korth, C., Sive, H., Singh, K. K., and Sawa, A. (2009). Understanding the role of DISC1 in psychiatric disease and during normal development. J. Neurosci. 29, 12768-12775.

Brownlees, J., Irving, N. G., Brion, J. P., Gibb, B. J., Wagner, U., Woodgett, J., and Miller, C. C. (1997). Tau phosphorylation in transgenic mice expressing glycogen synthase kinase-3beta transgenes. Neuroreport 8, 3251-3255.
Bullock, B. P., and Habener, J. F. (1998). Phosphorylation of the cAMP response element binding protein CREB by CAMPdependent protein kinase $\mathrm{A}$ and glycogen synthase kinase-3 alters DNA-binding affinity, conformation, and increases net charge. Biochemistry 37, 3795-3809.

Buss, H., Dörrie, A., Schmitz, M. L., Frank, R., Livingstone, M., Resch, K., and Kracht, M. (2004). Phosphorylation of serine 468 by GSK-3beta negatively regulates basal p65 NFkappaB activity. J. Biol. Chem. 279, 49571-49574.

Cai, X., Li, M., Vrana, J., and Schaller, M. D. (2006). Glycogen synthase kinase 3- and extracellular signal-regulated kinase-dependent phosphorylation of paxillin regulates cytoskeletal rearrangement. Mol. Cell. Biol. 26, 2857-2868.

Camargo, L. M., Collura, V., Rain, J. C., Mizuguchi, K., Hermjakob, H., Kerrien, S., Bonnert, T. P., Whiting, P. J., and Brandon, N. J. (2007). Disrupted in schizophrenia 1 interactome: evidence for the close connectivity of risk genes and a potential synaptic basis for schizophrenia. Mol. Psychiatry 12, 74-86.

Cho, J. H., and Johnson, G. V. (2004). Primed phosphorylation of tau at Thr231 by glycogen synthase kinase 3beta (GSK3beta) plays a critical role in regulating tau's ability to bind and stabilize microtubules. $J$. Neurochem. 88, 349-358.

Chou, H. Y., Howng, S. L., Cheng, T. S., Hsiao, Y. L., Lieu, A. S., Loh, J. K., Hwang, S. L., Lin, C. C., Hsu, C. M., Wang, C., Lee, C. I., Lu, P. J., Chou, C. K., Huang, C. Y., and Hong, Y. R. (2006). GSKIP is homologous to the Axin GSK3beta interaction domain and functions as a negative regulator of GSK3beta. Biochemistry 45, 11379-11389.

Chu, B., Soncin, F., Price, B. D., Stevenson, M. A., and Calderwood, S. K. (1996). Sequential phosphorylation by mitogen-activated protein kinase and glycogen synthase kinase 3 represses transcriptional activation by heat shock factor-1. J. Biol. Chem. 271, 30847-30857.

Chubb, J. E., Bradshaw, N. J., Soares, D. C., Porteous, D. J., and Millar, J. K. (2008). The DISC locus in psychiatric illness. Mol. Psychiatry 13, 36-64.

Clapcote, S. J., Lipina, T. V., Millar, J. K., Mackie, S., Christie, S., Ogawa, F., Lerch, J. P., Trimble, K., Uchiyama, M., Sakuraba, Y., Kaneda, H., Shiroishi, T., Houslay,
M. D., Henkelman, R. M., Sled, J. G., Gondo, Y., Porteous, D. J., and Roder, J. C. (2007). Behavioral phenotypes of Discl missense mutations in mice. Neuron 54 387-402.

Clayton, E. L., Sue, N., Smillie, K. J., O'Leary, T., Bache, N., Cheung, G., Cole, A. R., Wyllie, D. J., Sutherland, C., Robinson, P. J., and Cousin, M. A. (2010). Dynamin I phosphorylation by GSK3 controls activity-dependent bulk endocytosis of synaptic vesicles. Nat. Neurosci. 13, 845-851.

Cole, A., Frame, S., and Cohen, P. (2004a). Further evidence that the tyrosine phosphorylation of glycogen synthase kinase-3 (GSK3) in mammalian cells is an autophosphorylation event. Biochem. J. 377(Pt 1), 249-255.

Cole, A. R., Knebel, A., Morrice, N. A., Robertson, L. A., Irving, A. J., Connolly, C. N., and Sutherland, C. (2004b). GSK-3 phosphorylation of the Alzheimer epitope within collapsin response mediator proteins regulates axon elongation in primary neurons. J. Biol. Chem. 279, 50176-50180.

Cole, A. R., Causeret, F., Yadirgi, G., Hastie, C. J., McLauchlan, H. McManus, E. J., Hernández, F., Eickholt, B. J., Nikolic, M., and Sutherland, C. (2006). Distinct priming kinases contribute to differential regulation of collapsin response mediator proteins by glycogen synthase kinase- 3 in vivo. J. Biol. Chem. 281, 16591-16598.

Cornell, R. B., Kalmar, G. B., Kay, R. J., Johnson, M. A., Sanghera, J. S., and Pelech, S. L. (1995). Functions of the C-terminal domain of CTP: phosphocholine cytidylyltransferase. Effects of C-terminal deletions on enzyme activity, intracellular localization and phosphorylation potential. Biochem. J. 310 (Pt 2), 699-708.

Cross, D. A., Alessi, D. R., Cohen, P., Andjelkovich, M., and Hemmings, B. A. (1995). Inhibition of glycogen synthase kinase- 3 by insulin mediated by protein kinase B. Nature 378 , 785-789.

Cselenyi, C. S., Jernigan, K. K., Tahinci, E., Thorne, C. A., Lee, L. A., and Lee, E. (2008). LRP6 transduces a canonical Wnt signal independently of Axin degradation by inhibiting GSK3's phosphorylation of betacatenin. Proc. Natl. Acad. Sci. U.S.A. 105, 8032-8037.

Dajani, R., Fraser, E., Roe, S. M., Young, N., Good, V., Dale, T. C. and Pearl, L. H. (2001). Crystal structure of glycogen synthase kinase 3 beta: structural basis for phosphate-primed substrate specificity and autoinhibition. Cell 105, 721-732.

de Groot, R. P., Auwerx, J., Bourouis, M., and Sassone-Corsi, P. (1993). Negative regulation of Jun/AP-1: conserved function of glycogen synthase kinase 3 and the Drosophila kinase shaggy. Oncogene 8, 841-847.

Demarchi, F., Bertoli, C., Sandy, P., and Schneider, C. (2003). Glycogen synthase kinase- 3 beta regulates NF-kappa B1/p105 stability. J. Biol. Chem. 278, 39583-39590.

Dent, P., Campbell, D. G., Hubbard, M. J., and Cohen, P. (1989). Multisite phosphorylation of the glycogen-binding subunit of protein phosphatase-1G by cyclic AMPdependent protein kinase and glycogen synthase kinase-3. FEBS Lett. 248, 67-72.

DePaoli-Roach, A. A. (1984). Synergistic phosphorylation and activation of ATP-Mg-dependent phosphoprotein phosphatase by F A/GSK-3 and casein kinase II (PC0.7). J. Biol. Chem. 259, 12144-12152.

DePaoli-Roach, A. A., Ahmad, Z., Camici, M., Lawrence, J. C. Jr., and Roach, P. J. (1983). Multiple phosphorylation of rabbit skeletal muscle glycogen synthase. Evidence for interactions among phosphorylation sites and the resolution of electrophoretically distinct forms of the subunit. J. Biol. Chem. 258, 10702-10709.

Diehl, J. A., Cheng, M., Roussel, M. F., and Sherr, C. J. (1998). Glycogen synthase kinase-3beta regulates cyclin D1 proteolysis and subcellular localization. Genes Dev. 12, 3499-3511.

Ding, Q., He, X., Hsu, J. M., Xia, W., Chen, C. T., Li, L. Y., Lee, D. F., Liu, J. C., Zhong, Q., Wang, X., and Hung, M. C. (2007). Degradation of Mcl- 1 by beta-TrCP mediates glycogen synthase kinase 3 -induced tumor suppression and chemosensitization. Mol. Cell. Biol. 27, 4006-4017.

Ding, Q., Xia, W., Liu, J. C., Yang, J. Y., Lee, D. F., Xia, J., Bartholomeusz, G., Li, Y., Pan, Y., Li, Z., Bargou, R. C., Qin, J., Lai, C. C., Tsai, F. J., Tsai, C. H., and Hung, M. C. (2005). Erk associates with and primes GSK3beta for its inactivation resulting in upregulation of beta-catenin. Mol. Cell 19, 159-170. 
Doble, B. W., Patel, S., Wood, G. A., Kockeritz, L. K., and Woodgett, J. R. (2007). Functional redundancy of GSK-3alpha and GSK-3beta in Wnt/beta-catenin signaling shown by using an allelic series of embryonic stem cell lines. Dev. Cell 12, 957-971.

Doble, B. W., and Woodgett, J. R. (2003). GSK-3: tricks of the trade for a multi-tasking kinase. J. Cell. Sci. 116(Pt 7), 1175-1186.

Dominguez, I., Itoh, K., and Sokol, S. Y. (1995). Role of glycogen synthase kinase 3 beta as a negative regulator of dorsoventral axis formation in Xenopus embryos. Proc. Natl. Acad. Sci. U.S.A. 92, 8498-8502.

Donella-Deana, A., Pinna, L. A., Hemmings, B., and Cohen, P. (1983). Phosphorylation of K-casein by glycogen synthase kinase-3 from rabbit skeletal muscle. Biochim. Biophys. Acta 745, 149-153.

Eldar-Finkelman, H., and Krebs, E. G. (1997). Phosphorylation of insulin receptor substrate 1 by glycogen synthase kinase 3 impairs insulin action. Proc. Natl. Acad. Sci. U.S.A. 94, 9660-9664.

Eldar-Finkelman, H., Seger, R., Vandenheede, J. R., and Krebs, E. G. (1995). Inactivation of glycogen synthase kinase-3 by epidermal growth factor is mediated by mitogen-activated protein kinase/p90 ribosomal protein S6 kinase signaling pathway in NIH/3T3 cells. J. Biol. Chem. 270, 987-990.

Emamian, E. S., Hall, D., Birnbaum, M. J., Karayiorgou, M., and Gogos, J. A. (2004). Convergent evidence for impaired AKT1-GSK3beta signaling in schizophrenia. Nat. Genet. 36, 131-137.

Embi, N., Rylatt, D. B., and Cohen, P. (1980). Glycogen synthase kinase-3 from rabbit skeletal muscle. Separation from cyclic-AMP-dependent protein kinase and phosphorylase kinase. Eur. J. Biochem. 107, 519-527.

Engel, T., Hernandez, F., Avila, J., and Lucas, J. J. (2006). Full reversal of Alzheimer's disease-like phenotype in a mouse model with conditional overexpression of glycogen synthase kinase-3. J. Neurosci. 26, 5083-5090.

Engelmann, W. (1988). Evolution and selective advantage of circadian rhythms. Acta Physiol. Pol. 39, 345-356.

Eom, T. Y., and Jope, R. S. (2009). Blocked inhibitory serinephosphorylation of glycogen synthase kinase-3alpha/beta impairs in vivo neural precursor cell proliferation. Biol. Psychiatry 66, 494-502.

Espinosa, L., Ingles-Esteve, J., Aguilera, C., and Bigas, A. (2003). Phosphorylation by glycogen synthase kinase-3 beta down-regulates Notch activity, a link for Notch and Wnt pathways. J. Biol. Chem. 278, 32227-32235.

Fang, X., Yu, S., Tanyi, J. L., Lu, Y., Woodgett, J. R., and Mills, G. B. (2002). Convergence of multiple signaling cascades at glycogen synthase kinase 3: Edg receptor-mediated phosphorylation and inactivation by lysophosphatidic acid through a protein kinase $\mathrm{C}$-dependent intracellular pathway. Mol. Cell. Biol. 22, 2099-2110.

Fang, X., Yu, S. X., Lu, Y., Bast, R. C. Jr., Woodgett, J. R., and Mills, G. B. (2000). Phosphorylation and inactivation of glycogen synthase kinase 3 by protein kinase A. Proc. Natl. Acad. Sci. U.S.A. 97, 11960-11965.

Ferrarese, A., Marin, O., Bustos, V. H., Venerando, A., Antonelli, M., Allende, J. E., and Pinna, L. A. (2007). Chemical dissection of the APC repeat 3 multistep phosphorylation by the concerted action of protein kinases CK1 and GSK3. Biochemistry 46, 11902-11910.

Ferrer, I., Barrachina, M., and Puig, B. (2002). Glycogen synthase kinase-3 is associated with neuronal and glial hyperphosphorylated tau deposits in Alzheimer's disease, Pick's disease, progressive supranuclear palsy and corticobasal degeneration. Acta Neuropathol. 104, 583-591.

Fiol, C. J., Mahrenholz, A. M., Wang, Y., Roeske, R. W., and Roach, P. J. (1987). Formation of protein kinase recognition sites by covalent modification of the substrate. Molecular mechanism for the synergistic action of casein kinase II and glycogen synthase kinase 3. J. Biol. Chem. 262, 14042-14048.

Fiol, C. J., Wang, A., Roeske, R. W., and Roach, P. J. (1990). Ordered multisite protein phosphorylation. Analysis of glycogen synthase kinase 3 action using model peptide substrates. J. Biol. Chem. 265, 6061-6065.

Fiol, C. J., Williams, J. S., Chou, C. H., Wang, Q. M., Roach, P. J., Andrisani, O. M. (1994). A secondary phosphorylation of CREB341 at Ser129 is required for the CAMP-mediated control of gene expression. A role for glycogen synthase kinase- 3 in the control of gene expression. J. Biol. Chem. 269, 32187-32193.
Flugel, D., Gorlach, A., Michiels, C., and Kietzmann, T. (2007). Glycogen synthase kinase 3 phosphorylates hypoxia-inducible factor lalpha and mediates its destabilization in a VHL-independent manner. Mol. Cell. Biol. 27, 3253-3265.

Foltz, D. R., Santiago, M. C., Berechid, B. E., and Nye, J. S. (2002). Glycogen synthase kinase-3beta modulates notch signaling and stability. Curr. Biol. 12, 1006-1011.

Frame, S., and Cohen, P. (2001). GSK3 takes centre stage more than 20 years after its discovery. Biochem. J. 359(Pt 1), 1-16.

Frame, S., Cohen, P., and Biondi, R. M. (2001). A common phosphate binding site explains the unique substrate specificity of GSK3 and its inactivation by phosphorylation. Mol. Cell 7, 1321-1327.

Franca-Koh, J., Yeo, M., Fraser, E., Young, N., and Dale, T. C. (2002). The regulation of glycogen synthase kinase-3 nuclear export by Frat/GBP. J. Biol. Chem. 277, 43844-43848.

Fraser, E., Young, N., Dajani, R., FrancaKoh, J., Ryves, J., Williams, R. S., Yeo, M., Webster, M. T., Richardson, C., Smalley, M. J., Pearl, L. H., Harwood, A., and Dale, T. C. (2002). Identification of the axin and FRAT binding region of glycogen synthase kinase-3. J. Biol. Chem. 277, 2176-2185.

Freyberg, Z., Ferrando, S. J., and Javitch, J. A. (2009). Roles of the Akt/GSK-3 and Wnt signaling pathways in schizophrenia and antipsychotic drug action. Am. J. Psychiatry 167, 388-396

Fuentealba, L. C., Eivers, E., Ikeda, A., Hurtado, C., Kuroda, H., Pera, E. M., and De Robertis, E. M. (2007). Integrating patterning signals: Wnt/GSK3 regulates the duration of the BMP/Smad1 signal. Cell 131, 980-993.

Fujimuro, M., Wu, F. Y., ApRhys, C., Kajumbula, H., Young, D. B., Hayward, G. S., and Hayward, S. D. (2003). A novel viral mechanism for dysregulation of beta-catenin in Kaposi's sarcoma-associated herpesvirus latency. Nat. Med. 9, 300-306.

Gomez-Sintes, R., Hernandez, F. Bortolozzi, A., Artigas, F., Avila, J., Zaratin, P., Gotteland, J. P., and Lucas, J. J. (2007). Neuronal apoptosis and reversible motor deficit in dominant-negative GSK-3 conditional transgenic mice. $E M B O$ J. 26, 2743-2754.
Goode, N., Hughes, K., Woodgett, J. R., and Parker, P. J. (1992). Differential regulation of glycogen synthase kinase- 3 beta by protein kinase C isotypes. J. Biol. Chem. 267, 16878-16882.

Gould, T. D. (2006). Targeting glycogen synthase kinase- 3 as an approach to develop novel mood-stabilising medications. Expert Opin. Ther. Targets 10, 377-392.

Grimes, C. A., and Jope, R. S. (2001). CREB DNA binding activity is inhibited by glycogen synthase kinase- 3 beta and facilitated by lithium. J. Neurochem. 78, 1219-1232.

Guan, R. J., Khatra, B. S., and Cohlberg, J. A. (1991). Phosphorylation of bovine neurofilament proteins by protein kinase FA (glycogen synthase kinase 3). J. Biol. Chem. 266, 8262-8267.

Guo, X., Ramirez, A., Waddell, D. S., Li, Z., Liu, X., and Wang, X. F. (2008). Axin and GSK3- control Smad3 protein stability and modulate TGF- signaling. Genes Dev. 22, 106-120.

Gustafson, M. P., Welcker, M., Hwang, H. C., and Clurman, B. E. (2005). Zcchc8 is a glycogen synthase kinase3 substrate that interacts with RNAbinding proteins. Biochem. Biophys. Res. Commun. 338, 1359-1367.

Hagen, T., Di Daniel, E., Culbert, A. A., and Reith, A. D. (2002). Expression and characterization of GSK-3 mutants and their effect on beta-catenin phosphorylation in intact cells. J. Biol. Chem. 277, 23330-23335.

Hagen, T., and Vidal-Puig, A. (2002). Characterisation of the phosphorylation of beta-catenin at the GSK-3 priming site Ser45. Biochem. Biophys. Res. Commun. 294, 324-328.

Han, S. I., Aramata, S., Yasuda, K., and Kataoka, K. (2007). MafA stability in pancreatic beta cells is regulated by glucose and is dependent on its constitutive phosphorylation at multiple sites by glycogen synthase kinase 3. Mol. Cell. Biol. 27, 6593-6605.

Hanger, D. P., Hughes, K., Woodgett, J. R., Brion, J. P., and Anderton, B. H. (1992). Glycogen synthase kinase3 induces Alzheimer's disease-like phosphorylation of tau: generation of paired helical filament epitopes and neuronal localisation of the kinase. Neurosci. Lett. 147, 58-62.

Hanks, S. K., and Hunter, T. (1995). Protein kinases 6 . The eukaryotic protein kinase superfamily: kinase (catalytic) domain structure and classification. FASEB J. 9, 576-596. 
Happel, N., Stoldt, S., Schmidt, B., and Doenecke, D. (2009). M phasespecific phosphorylation of histone $\mathrm{H} 1.5$ at threonine 10 by GSK-3. J. Mol. Biol. 386, 339-350.

Harada, Y., Sakai, M., Kurabayashi, N., Hirota, T., and Fukada, Y. (2005). Ser-557-phosphorylated mCRY2 is degraded upon synergistic phosphorylation by glycogen synthase kinase-3 beta. J. Biol. Chem. 280, 31714-31721.

Harrison, P. J., and Weinberger, D. R. (2005). Schizophrenia genes, gene expression, and neuropathology: on the matter of their convergence. Mol. Psychiatry 10, 40-68.

Hart, M. J., de los Santos, R., Albert, I. N., Rubinfeld, B., and Polakis, P. (1998). Downregulation of beta-catenin by human axin and its association with the APC tumor suppressor, betacatenin and GSK3 beta. Curr. Biol. 8, 573-581.

He, X., Semenov, M., Tamai, K., and Zeng, X. (2004). LDL receptorrelated proteins 5 and 6 in Wnt/betacatenin signaling: arrows point the way. Development 131, 1663-1677.

Hemmings, B. A., Aitken, A., Cohen, P., Rymond, M., and Hofmann, F. (1982). Phosphorylation of the typeII regulatory subunit of cyclic-AMPdependent protein kinase by glycogen synthase kinase 3 and glycogen synthase kinase 5. Eur. J. Biochem. 127, 473-481.

Hergovich, A., Lisztwan, J., Thoma, C. R., Wirbelauer, C., Barry, R. E., and Krek, W. (2006). Priming-dependent phosphorylation and regulation of the tumor suppressor pVHL by glycogen synthase kinase 3. Mol. Cell. Biol. 26, 5784-5796.

Hernandez, F., Borrell, J., Guaza, C., Avila, J., and Lucas, J. J. (2002). Spatial learning deficit in transgenic mice that conditionally over-express GSK-3beta in the brain but do not form tau filaments. J. Neurochem. 83, 1529-1533.

Hernandez, F., Perez, M., Lucas, J. J., Mata, A. M., Bhat, R., and Avila, J. (2004). Glycogen synthase kinase3 plays a crucial role in tau exon 10 splicing and intranuclear distribution of SC35. Implications for Alzheimer's disease. J. Biol. Chem. 279, 3801-3806.

Heyd, F., and Lynch, K. W. (2010). Phosphorylation-dependent regulation of PSF by GSK3 controls CD45 alternative splicing. Mol. Cell 40, 126-137.

Higgins, M. J., Graves, P. R., and Graves, L. M. (2007). Regulation of human cytidine triphosphate synthetase 1 by glycogen synthase kinase 3. J. Biol. Chem. 282, 29493-29503.
Hilioti, Z., Gallagher, D. A., Low-Nam, S. T., Ramaswamy, P., Gajer, P. Kingsbury, T. J., Birchwood, C. J., Levchenko, A., and Cunningham, $\mathrm{K}$. W. (2004). GSK-3 kinases enhance calcineurin signaling by phosphorylation of RCNs. Genes Dev. 18, 35-47.

Hirota, T., Lewis, W. G., Liu, A. C., Lee, J. W., Schultz, P. G., and Kay, S. A. (2008). A chemical biology approach reveals period shortening of the mammalian circadian clock by specific inhibition of GSK-3beta. Proc. Natl. Acad. Sci. U.S.A. 105, 20746-20751.

Hoeflich, K. P., Luo, J., Rubie, E. A., Tsao, M. S., Jin, O., and Woodgett, J. R. (2000). Requirement for glycogen synthase kinase-3beta in cell survival and NF-kappaB activation. Nature 406, 86-90.

Hong, Y. R., Chen, C. H., Chang, J. H., Wang, S., Sy, W. D., Chou, C. K., and Howng, S. L. (2000). Cloning and characterization of a novel human ninein protein that interacts with the glycogen synthase kinase 3beta. Biochim. Biophys. Acta 1492, 513-516.

Hong, Y. R., Chen, C. H., Cheng, D. S., Howng, S. L., and Chow, C. C. (1998). Human dynamin-like protein interacts with the glycogen synthase kinase 3beta. Biochem. Biophys. Res. Commun. 249, 697-703.

Hooper, C., Markevich, V., Plattner, F., Killick, R., Schofield, E., Engel, T., Hernandez, F., Anderton, B., Rosenblum, K., Bliss, T., Cooke, S. F., Avila, J., Lucas, J. J., Giese, K. P., Stephenson, J., and Lovestone, S. (2007). Glycogen synthase kinase-3 inhibition is integral to long-term potentiation. Eur. J. Neurosci. 25, 81-86.

Hoshi, M., Sato, M., Kondo, S., Takashima, A., Noguchi, K., Takahashi, M., Ishiguro, K., and Imahori, K. (1995). Different localization of tau protein kinase I/glycogen synthase kinase-3 beta from glycogen synthase kinase-3 alpha in cerebellum mitochondria. J. Biochem. 118, 683-685.

Hoshi, M., Takashima, A., Noguchi, K., Murayama, M., Sato, M., Kondo, S., Saitoh, Y., Ishiguro, K., Hoshino, T., and Imahori, K. (1996). Regulation of mitochondrial pyruvate dehydrogenase activity by tau protein kinase I/glycogen synthase kinase 3beta in brain. Proc. Natl. Acad.Sci.U.S.A. 93, 2719-2723.

Howng, S. L., Hsu, H. C., Cheng, T. S., Lee, Y. L., Chang, L. K., Lu, P. J., and Hong, Y. R. (2004). A novel ninein-interaction protein, CGI-99, blocks ninein phosphorylation by GSK3beta and is highly expressed in brain tumors. FEBS Lett. 566, 162-168.

Hughes, K., Nikolakaki, E., Plyte, S. E., Totty, N. F., and Woodgett, J. R. (1993). Modulation of the glycogen synthase kinase- 3 family by tyrosine phosphorylation. EMBO J. 12, 803-808.

Hughes, K., Ramakrishna, S., Benjamin, W. B., and Woodgett, J. R. (1992). Identification of multifunctional ATP-citrate lyase kinase as the alpha-isoform of glycogen synthase kinase-3. Biochem. J. 288(Pt 1), 309-314.

Iitaka, C., Miyazaki, K., Akaike, T., and Ishida, N. (2005). A role for glycogen synthase kinase-3beta in the mammalian circadian clock. J. Biol. Chem 280, 29397-29402.

Ikeda, S., Kishida, M., Matsuura, Y. Usui, H., and Kikuchi, A. (2000). GSK-3beta-dependent phosphorylation of adenomatous polyposis coli gene product can be modulated by beta-catenin and protein phosphatase 2A complexed with axin. Oncogene 19, 537-545.

Ikeda, S., Kishida, S., Yamamoto, H. Murai, H., Koyama, S., and Kikuchi, A. (1998). Axin, a negative regulator of the Wnt signaling pathway, forms a complex with GSK-3beta and beta-catenin and promotes GSK-3beta-dependent phosphorylation of beta-catenin. EMBO J. 17, 1371-1384.

Inoki, K., Ouyang, H., Zhu, T., Lindvall, C., Wang, Y., Zhang, X., Yang, Q., Bennett, C., Harada, Y., Stankunas, K., Wang, C. Y., He, X., MacDougald, O. A., You, M., Williams, B. O., and Guan, K. L. (2006). TSC2 integrates Wnt and energy signals via a coordinated phosphorylation by AMPK and GSK3 to regulate cell growth. Cell 126, 955-968.

Iwahana, E., Akiyama, M., Miyakawa, K., Uchida, A., Kasahara, J., Fukunaga, K., Hamada, T., and Shibata, S. (2004). Effect of lithium on the circadian rhythms of locomotor activity and glycogen synthase kinase3 protein expression in the mouse suprachiasmatic nuclei. Eur. J. Neurosci. 19, 2281-2287.

Jaaro-Peled, H., Hayashi-Takagi, A. Seshadri, S., Kamiya, A., Brandon, N. J., and Sawa, A. (2009). Neurodevelopmental mechanisms of schizophrenia: understanding disturbed postnatal brain maturation through neuregulin-1-ErbB4 and DISC1. Trends Neurosci. 32, 485-495.

Jho, E., Lomvardas, S., and Costantini, F. (1999). A GSK3beta phosphorylation site in axin modulates interaction with beta-catenin and Tcf-mediated gene expression. Biochem. Biophys. Res. Commun. 266, 28-35.

Jia, J., Amanai, K., Wang, G., Tang, J., Wang, B., and Jiang, J. (2002). Shaggy/GSK3 antagonizes hedgehog signalling by regulating Cubitus interruptus. Nature 416, 548-552.

Jope, R. S., and Johnson, G. V. (2004). The glamour and gloom of glycogen synthase kinase-3. Trends Biochem. Sci. 29, 95-102.

Kaidanovich-Beilin, O., Lipina, T. V., Takao, K., van Eede, M., Hattori, S., Laliberté, C., Khan, M., Okamoto, K., Chambers, J. W., Fletcher, P. J., MacAulay, K., Doble, B. W., Henkelman, M., Miyakawa, T., Roder, J., and Woodgett, J. R. (2009). Abnormalities in brain structure and behavior in GSK-3alpha mutant mice. $\mathrm{Mol}$ Brain 2, 35

Kaladchibachi, S. A., Doble, B., Anthopoulos, N., Woodgett, J. R., and Manoukian, A. S. (2007). Glycogen synthase kinase 3, circadian rhythms, and bipolar disorder: a molecular link in the therapeutic action of lithium. J. Circadian. Rhythms 5, 3.

Kang, T., Wei, Y., Honaker, Y., Yamaguchi, H., Appella, E., Hung, M. C., Piwnica-and Worms, H. (2008). GSK-3 beta targets Cdc25A for ubiquitin-mediated proteolysis, and GSK-3 beta inactivation correlates with Cdc25A overproduction in human cancers. Cancer Cell 13, 36-47.

Kang, U. G., Seo, M. S., Roh, M. S., Kim, Y., Yoon, S. C., and Kim, Y. S. (2004) The effects of clozapine on the GSK3-mediated signaling pathway. FEBS Lett. 560, 115-119.

Kerkela, R., Kockeritz, L., Macaulay, K., Zhou, J., Doble, B. W., Beahm, C. Greytak, S., Woulfe, K., Trivedi, C. M., Woodgett, J. R., Epstein, J. A., Force, T., and Huggins, G. S. (2008). Deletion of GSK-3beta in mice leads to hypertrophic cardiomyopathy secondary to cardiomyoblast hyperproliferation. J. Clin. Invest. 118, 3609-3618.

Kim, L., Liu, J., and Kimmel, A. R. (1999). The novel tyrosine kinase ZAK1 activates GSK3 to direct cell fate specification. Cell 99, 399-408.

Kim, W. Y., Wang, X., Wu, Y., Doble, B. W., Patel, S., Woodgett, J. R., and Snider, W. D. (2009). GSK-3 is a master regulator of neural progenitor homeostasis. Nat. Neurosci. 12, 1390-13907.

Kimelman, D., and Xu, W. (2006). Beta-catenin destruction complex: insights and questions from a structural perspective. Oncogene 25, 7482-7491. 
Kimura, T., Yamashita, S., Nakao, S., Park, J. M., Murayama, M., Mizoroki, T., Yoshiike, Y., Sahara, N., and Takashima, A. (2008). GSK-3beta is required for memory reconsolidation in adult brain. PLoS ONE 3, e3540. doi:10.1371/journal.pone. 0003540

Kirschenbaum, F., Hsu, S. C., Cordell, B., and McCarthy, J. V. (2001). Glycogen synthase kinase-3beta regulates presenilin $1 \mathrm{C}$-terminal fragment levels. J. Biol. Chem. 276, 30701-30707.

Kitagawa, K., Hiramatsu, Y., Uchida, C., Isobe, T., Hattori, T., Oda, T., Shibata, K., Nakamura, S., Kikuchi, A., and Kitagawa, M. (2009). Fbw7 promotes ubiquitin-dependent degradation of c-Myb: involvement of GSK3-mediated phosphorylation of Thr-572 in mouse c-Myb. Oncogene 28, 2393-2405.

Klein, P. S., and Melton, D. A. (1996). A molecular mechanism for the effect of lithium on development. Proc. Natl. Acad. Sci. U.S.A. 93, 8455-8459.

Kockeritz, L., Doble, B., Patel, S., and Woodgett, J. R. (2006). Glycogen synthase kinase-3 - an overview of an over-achieving protein kinase. Curr. Drug Targets 7, 1377-1388.

Koros, E., and Dorner-Ciossek, C. (2007). The role of glycogen synthase kinase-3beta in schizophrenia. Drug News Perspect. 20, 437-445.

Kosuga, S., Tashiro, E., Kajioka, T., Ueki, M., Shimizu, Y., and Imoto, M. (2005). GSK-3beta directly phosphorylates and activates MARK2/PAR-1. J. Biol. Chem. 280, 42715-42722.

Krause, U., Bertrand, L., Maisin, L., Rosa, M., and Hue, L. (2002). Signalling pathways and combinatory effects of insulin and amino acids in isolated rat hepatocytes. Eur. J. Biochem. 269, 3742-3750.

Krymsky, M. A., Kudryashov, D. S., Shirinsky, V. P., Lukas, T. J., Watterson, D. M., and Vorotnikov, A. V. (2001). Phosphorylation of kinaserelated protein (telokin) in tonic and phasic smooth muscles. J. Muscle Res. Cell. Motil. 22, 425-437.

Kulikov, R., Boehme, K. A., and Blattner, C. (2005). Glycogen synthase kinase 3-dependent phosphorylation of $\mathrm{Mdm} 2$ regulates p53 abundance. Mol. Cell. Biol. 25, 7170-7180.

Kumar, P., Lyle, K. S., Gierke, S., Matov, A., Danuser, G., and Wittmann, T. (2009). GSK3beta phosphorylation modulates CLASP-microtubule association and lamella microtubule attachment. J. Cell Biol. 184, 895-908.
Kurabayashi, N., Hirota, T., Sakai, M., Sanada, K., and Fukada, Y. (2010). DYRK1A and glycogen synthase kinase 3beta, a dual-kinase mechanism directing proteasomal degradation of CRY2 for circadian timekeeping. Mol. Cell. Biol. 30, 1757-1768.

Kwiek, N. C., Thacker, D. F., and Haystead, T. A. (2007). Dual kinasemediated regulation of PITK by CaMKII and GSK3. Cell. Signal. 19, 593-599.

Kwok, J. B., Hallupp, M., Loy, C. T., Chan, D. K., Woo, J., Mellick, G. D., Buchanan, D. D., Silburn, P. A., Halliday, G. M., and Schofield, P. R. (2005). GSK3B polymorphisms alter transcription and splicing in Parkinson's disease. Ann. Neurol. 58, 829-839.

Lau, K. F., Miller, C. C., Anderton, B. H., and Shaw, P. C. (1999). Expression analysis of glycogen synthase kinase3 in human tissues. J. Pept. Res. 54, 85-91.

Lee, E., Salic, A., Krüger, R., Heinrich, R., and Kirschner, M. W. (2003). The roles of APC and axin derived from experimental and theoretical analysis of the Wnt pathway. PLoS Biol. 1, e10. doi:10.1371/journal.pbio.0000010

Lee, F. H., Kaidanovich-Beilin, O., Roder, J. C., Woodgett, J. R., and Wong, A. H. (2011). Genetic inactivation of GSK3alpha rescues spine deficits in Discl-L100P mutant mice. Schizophr. Res. 129, 74-79.

Leroy, K., and Brion, J. P. (1999). Developmental expression and localization of glycogen synthase kinase3 beta in rat brain. J. Chem. Neuroanat. 16, 279-293.

Lesort, M., Jope, R. S., and Johnson, G. V. (1999). Insulin transiently increases tau phosphorylation: involvement of glycogen synthase kinase-3beta and Fyn tyrosine kinase. J. Neurochem. 72, 576-584.

Li, L., Yuan, H., Weaver, C. D., Mao, J., Farr, G. H. III, Sussman, D. J., Jonkers, J., Kimelman, D., and Wu, D. (1999). Axin and FRAT1 interact with dvl and GSK, bridging Dvl to GSK in Wnt-mediated regulation of LEF-1. EMBO J. 18, 4233-4240.

Li, M., Wang, X., Meintzer, M. K., Laessig, T., Birnbaum, M. J., and Heidenreich, K. A. (2000). Cyclic AMP promotes neuronal survival by phosphorylation of glycogen synthase kinase 3beta. Mol. Cell. Biol. 20, 9356-9363.

Li, T., Hawkes, C., Qureshi, H. Y., Kar, S., and Paudel, H. K. (2006). Cyclindependent protein kinase 5 primes microtubule-associated protein tau site-specifically for glycogen synthase kinase 3beta. Biochemistry 45 , 3134-3145.

Li, X., Rosborough, K. M., Friedman, A. B., Zhu, W., and Roth, K. A. (2007). Regulation of mouse brain glycogen synthase kinase- 3 by atypical antipsychotics. Int. J. Neuropsychopharmacol. 10, 7-19.

Li, Y., Bharti, A., Chen, D., Gong, J. and Kufe, D. (1998). Interaction of glycogen synthase kinase 3beta with the DF3/MUC1 carcinomaassociated antigen and beta-catenin. Mol. Cell. Biol. 18, 7216-7224.

Liberman, Z., and Eldar-Finkelman, H. (2005). Serine 332 phosphorylation of insulin receptor substrate- 1 by glycogen synthase kinase- 3 attenuates insulin signaling. J. Biol. Chem. 280, 4422-4428.

Linding, R., Jensen, L. J., Ostheimer, G. J., van Vugt, M. A., Jørgensen, C., Miron, I. M., Diella, F., Colwill, K., Taylor, L., Elder, K., Metalnikov, P., Nguyen, V., Pasculescu, A., Jin, J., Park, J. G., Samson, L. D., Woodgett, J. R., Russell, R. B., Bork, P., Yaffe, M. B., and Pawson, T. (2007). Systematic discovery of in vivo phosphorylation networks. Cell 129, 1415-1426.

Lipina, T. V., Kaidanovich-Beilin, O. Patel, S., Wang, M., Clapcote, S. J., Liu, F., Woodgett, J. R., and Roder, J. C. (2011). Genetic and pharmacological evidence for schizophreniarelated Discl interaction with GSK3. Synapse 65, 234-248.

Litovchick, L., Chestukhin, A., and DeCaprio, J. A. (2004). Glycogen synthase kinase 3 phosphorylates RBL2/p130 during quiescence. Mol Cell. Biol. 24, 8970-8980.

Liu, C., Li, Y., Semenov, M., Han, C. Baeg, G. H., Tan, Y., Zhang, Z., Lin, X., and He, X. (2002). Control of beta-catenin phosphorylation/degradation by a dual-kinase mechanism. Cell 108, 837-847.

Liu, H. K., Perrier, S., Lipina, C., Finlay, D., McLauchlan, H., Hastie, C. J., Hundal, H. S., and Sutherland, C. (2006). Functional characterisation of the regulation of CAAT enhancer binding protein alpha by GSK-3 phosphorylation of Threonines 222/226. BMC Mol. Biol. 7 14. doi:10.1186/1471-2199-7-14

Liu, S. J., Zhang, A. H., Li, H. L., Wang, Q., Deng, H. M., Netzer, W. J., Xu, H., and Wang, J. Z. (2003). Overactivation of glycogen synthase kinase-3 by inhibition of phosphoinositol-3 kinase and protein kinase $\mathrm{C}$ leads to hyperphosphorylation of tau and impairment of spatial memory. $J$.
Neurochem. 87, 1333-1344.

Lochhead, P. A., Kinstrie, R., Sibbet, G., Rawjee, T., Morrice, N., and Cleghon, V. (2006). A chaperonedependent GSK3beta transitional intermediate mediates activationloop autophosphorylation. Mol. Cell 24, 627-633.

Logan, C. Y., and Nusse, R. (2004). The Wnt signaling pathway in development and disease. Annu. Rev. Cell Dev. Biol. 20, 781-810.

Lovestone, S., Killick, R., Di Forti, M., and Murray, R. (2007). Schizophrenia as a GSK-3 dysregulation disorder. Trends Neurosci. 30, 142-149.

Lu, Y., Muller, M., Smith, D., Dutta, B., Komurov, K., Iadevaia, S., Ruths, D., Tseng, J. T., Yu, S., Yu, Q., Nakhleh, L., Balazsi, G., Donnelly, J., Schurdak, M., Morgan-Lappe, S., Fesik, S., Ram, P. T., and Mills, G. B. (2011). Kinome siRNA-phosphoproteomic screen identifies networks regulating AKT signaling. Oncogene 30, 4567-4577.

Lucas, F. R., Goold, R. G., GordonWeeks, P. R., and Salinas, P. C. (1998). Inhibition of GSK-3beta leading to the loss of phosphorylated MAP-1B is an early event in axonal remodelling induced by WNT-7a or lithium. J. Cell. Sci. 111(Pt 10), 1351-1361.

Lucas, J. J., Hernandez, F., GómezRamos, P., Morán, M. A., Hen, R., and Avila, J. (2001). Decreased nuclear beta-catenin, tau hyperphosphorylation and neurodegeneration in GSK-3beta conditional transgenic mice. EMBO J. 20, 27-39.

Luo, W., Peterson, A., Garcia, B. A., Coombs, G., Kofahl, B., Heinrich, R., Shabanowitz, J., Hunt, D. F., Yost, H. J., and Virshup, D. M. (2007). Protein phosphatase 1 regulates assembly and function of the beta-catenin degradation complex. EMBO J. 26, 1511-1521.

Ma, Y. C., Song, M. R., Park, J. P., Henry Ho, H. Y., Hu, L., Kurtev, M. V., Zieg, J., Ma, Q., Pfaff, S. L., and Greenberg, M. E. (2008). Regulation of motor neuron specification by phosphorylation of neurogenin 2. Neuron 58, 65-77.

MacAulay, K., Doble, B. W., Patel, S., Hansotia, T., Sinclair, E. M., Drucker, D. J., Nagy, A., and Woodgett, J. R. (2007). Glycogen synthase kinase 3alpha-specific regulation of murine hepatic glycogen metabolism. Cell Metab. 6, 329-337.

MacDonald, B. T., Tamai, K., and He, X. (2009). Wnt/beta-catenin signaling: components, mechanisms, and diseases. Dev. Cell 17, 9-26. 
Mackie, K., Sorkin, B. C., Nairn, A. C., Greengard, P., Edelman, G. M., and Cunningham, B. A. (1989). Identification of two protein kinases that phosphorylate the neural celladhesion molecule, N-CAM. J. Neurosci. 9, 1883-1896.

Mai, L., Jope, R. S., and Li, X. (2002). BDNF-mediated signal transduction is modulated by GSK3beta and mood stabilizing agents. J. Neurochem. 82, 75-83.

Mao, Y., Ge, X., Frank, C. L., Madison, J. M., Koehler, A. N., Doud, M. K., Tassa, C., Berry, E. M., Soda, T., Singh, K. K., Biechele, T., Petryshen, T. L., Moon, R. T., Haggarty, S. J., and Tsai, L. H. (2009). Disrupted in schizophrenia 1 regulates neuronal progenitor proliferation via modulation of GSK3beta/beta-catenin signaling. Cell 136, 1017-1031.

Martinek, S., Inonog, S., Manoukian, A. S., and Young, M. W. (2001). A role for the segment polarity gene shaggy/GSK-3 in the Drosophila circadian clock. Cell 105, 769-779.

Maurer, U., Charvet, C., Wagman, A. S., Dejardin, E., and Green, D. R. (2006). Glycogen synthase kinase-3 regulates mitochondrial outer membrane permeabilization and apoptosis by destabilization of MCL-1. Mol. Cell 21, 749-760.

McManus, E. J., Sakamoto, K., Armit, L. J., Ronaldson, L., Shpiro, N., Marquez, R., and Alessi, D. R. (2005). Role that phosphorylation of GSK3 plays in insulin and Wnt signalling defined by knock in analysis. EMBO J. 24, 1571-1583.

McNeill, H., and Woodgett, J. R. (2010). When pathways collide: collaboration and connivance among signalling proteins in development. Nat. Rev. Mol. Cell Biol. 11, 404-413.

Meares, G. P., and Jope, R. S. (2007). Resolution of the nuclear localization mechanism of glycogen synthase kinase-3: functional effects in apoptosis. J. Biol. Chem. 282, 16989-17001.

Mi, K., Dolan, P. J., and Johnson, G. V. (2006). The low density lipoprotein receptor-related protein 6 interacts with glycogen synthase kinase 3 and attenuates activity. J. Biol. Chem. 281, 4787-4794.

Michalak, M., Fu, S. Y., Milner, R. E., Busaan, J. L., and Hance, J. E. (1996). Phosphorylation of the carboxyl-terminal region of dystrophin. Biochem. Cell Biol. 74, 431-437.

Millar, J. K., Wilson-Annan, J. C., Anderson, S., Christie, S., Taylor, M. S.,
Semple, C. A., Devon, R. S., St Clair, D. M., Muir, W. J., Blackwood, D. H., and Porteous, D. J. (2000). Disruption of two novel genes by a translocation co-segregating with schizophrenia. Hum. Mol. Genet. 9, 1415-1423.

Miller, M. W., Caracciolo, M. R., Berlin, W. K., and Hanover, J. A. (1999). Phosphorylation and glycosylation of nucleoporins. Arch. Biochem. Biophys. 367, 51-60.

Mines, M. A., Yuskaitis, C. J., King, M. K., Beurel, E., and Jope, R. S. (2010). GSK3 influences social preference and anxiety-related behaviors during social interaction in a mouse model of fragile X syndrome and autism. PLoS ONE 5, e9706. doi:10.1371/journal.pone.0009706

Mishra, R., Barthwal, M. K., Sondarva, G., Rana, B., Wong, L., Chatterjee, M., Woodgett, J. R., and Rana, A. (2007). Glycogen synthase kinase3beta induces neuronal cell death via direct phosphorylation of mixed lineage kinase 3. J. Biol. Chem. 282, 30393-30405.

Moon, R. T., Kohn, A. D., De Ferrari, G. V., and Kaykas, A. (2004). WNT and beta-catenin signalling: diseases and therapies. Nat. Rev. Genet. 5, 691-701.

Moore, K. B., Schneider, M. L., and Vetter, M. L. (2002). Posttranslational mechanisms control the timing of bHLH function and regulate retinal cell fate. Neuron 34, 183-195.

Moreno, F. J., and Avila, J. (1998). Phosphorylation of stathmin modulates its function as a microtubule depolymerizing factor. Mol. Cell. Biochem. 183, 201-209.

Morfini, G., Szebenyi, G., Elluru, R., Ratner, N., and Brady, S. T. (2002). Glycogen synthase kinase 3 phosphorylates kinesin light chains and negatively regulates kinesin-based motility. EMBO J. 21, 281-293.

Morisco, C., Seta, K., Hardt, S. E., Lee, Y., Vatner, S. F., and Sadoshima, J. (2001). Glycogen synthase kinase 3beta regulates GATA4 in cardiac myocytes. J. Biol. Chem. 276, 28586-28597.

Morton, S., Davis, R. J., McLaren, A., and Cohen, P. (2003). A reinvestigation of the multisite phosphorylation of the transcription factor c-Jun. EMBO J. 22, 3876-3886.

Mottet, D., Dumont, V., Deccache, Y., Demazy, C., Ninane, N., Raes, M., and Michiels, C. (2003). Regulation of hypoxia-inducible factor-1alpha protein level during hypoxic conditions by the phosphatidylinositol 3kinase/Akt/glycogen synthase kinase 3beta pathway in HepG2 cells. J. Biol. Chem. 278, 31277-31285.

Mukai, F., Ishiguro, K., Sano, Y., and Fujita, S. C. (2002). Alternative splicing isoform of tau protein kinase I/glycogen synthase kinase 3 beta. J. Neurochem. 81, 1073-1083.

Murray, J. T., Campbell, D. G., Morrice, N., Auld, G. C., Shpiro, N., Marquez, R., Peggie, M., Bain, J., Bloomberg, G. B., Grahammer, F. Lang, F., Wulff, P., Kuhl, D., and Cohen, P. (2004). Exploitation of KESTREL to identify NDRG family members as physiological substrates for SGK1 and GSK3. Biochem. J. 384(Pt 3), 477-488.

Neal, J. W., and Clipstone, N. A. (2001). Glycogen synthase kinase- 3 inhibits the DNA binding activity of NFATc. J. Biol. Chem. 276, 3666-3673.

Niehrs, C., and Shen, J. (2010). Regulation of Lrp6 phosphorylation. Cell. Mol. Life Sci. 67, 2551-2562.

Nikolakaki, E., Coffer, P. J., Hemelsoet, R., Woodgett, J. R., and Defize, L. H. (1993). Glycogen synthase kinase 3 phosphorylates Jun family members in vitro and negatively regulates their transactivating potential in intact cells. Oncogene 8 , 833-840.

Nishi, Y., and Lin, R. (2005). DYRK2 and GSK-3 phosphorylate and promote the timely degradation of OMA-1, a key regulator of the oocyte-toembryo transition in C. elegans. Dev. Biol. 288, 139-149.

Nishimura, I., Yang, Y., and Lu, B. (2004). PAR-1 kinase plays an initiator role in a temporally ordered phosphorylation process that confers tau toxicity in Drosophila. Cell 116, 671-682.

Noble, W., Olm, V., Takata, K., Casey, E., Mary, O., Meyerson, J., Gaynor, K., LaFrancois, J., Wang, L., Kondo, T., Davies, P., Burns, M., Veeranna Nixon, R., Dickson, D., Matsuoka, Y., Ahlijanian, M., Lau, L. F., and Duff, K. (2003). Cdk5 is a key factor in tau aggregation and tangle formation in vivo. Neuron 38, 555-565.

Noble, W., Planel, E., Zehr, C., Olm, V., Meyerson, J., Suleman, F., Gaynor, K., Wang, L., LaFrancois, J., Feinstein, B., Burns, M., Krishnamurthy, P., Wen, Y., Bhat, R., Lewis, J., Dickson, D., and Duff, K. (2005). Inhibition of glycogen synthase kinase-3 by lithium correlates with reduced tauopathy and degeneration in vivo. Proc. Natl. Acad. Sci. U.S.A. 102, 6990-6995.

O’Brien, W. T., Harper, A. D., Jové, F., Woodgett, J. R., Maretto, S., Piccolo,
S., and Klein, P. S. (2004). Glycogen synthase kinase-3beta haploinsufficiency mimics the behavioral and molecular effects of lithium. $J$. Neurosci. 24, 6791-6798.

O’Brien, W. T., Huang, J., Buccafusca, R., Garskof, J., Valvezan, A. J., Berry, G. T., and Klein, P. S. (2011). Glycogen synthase kinase-3 is essential for beta-arrestin-2 complex formation and lithium-sensitive behaviors in mice. J. Clin. Invest. 121, 3756-3762.

Oh, M., Kim, H., Yang, I., Park, J. H., Cong, W. T., Baek, M. C., Bareiss, S., Ki, H., Lu, Q., No, J., Kwon, I., Choi, J. K., and Kim, K. (2009). GSK-3 phosphorylates delta-catenin and negatively regulates its stability via ubiquitination/proteosomemediated proteolysis. J. Biol. Chem. 284, 28579-28589.

Omata, N., Chiu, C. T., Moya, P. R., Leng, Y., Wang, Z., Hunsberger, J. G., Leeds, P., and Chuang, D. M. (2011). Lentivirally mediated GSK-3beta silencing in the hippocampal dentate gyrus induces antidepressant-like effects in stressed mice. Int. J. Neuropsychopharmacol. 14, 711-717.

Pandey, G. N., Dwivedi, Y., Rizavi, H. S., Teppen, T., Gaszner, G. L., Roberts, R. C., and Conley, R. R. (2009). GSK3beta gene expression in human postmortem brain: regional distribution, effects of age and suicide. Neurochem. Res. 34, 274-285.

Parker, P. J., Caudwell, F. B., and Cohen, P. (1983). Glycogen synthase from rabbit skeletal muscle; effect of insulin on the state of phosphorylation of the seven phosphoserine residues in vivo. Eur. J. Biochem. 130, 227-234.

Pastorino, J. G., Hoek, J. B., Shulga, N. (2005). Activation of glycogen synthase kinase 3beta disrupts the binding of hexokinase II to mitochondria by phosphorylating voltage-dependent anion channel and potentiates chemotherapyinduced cytotoxicity. Cancer Res. 65 , 10545-10554.

Patel, S., Macaulay, K., and Woodgett, J. R. (2011). Tissue-specific analysis of glycogen synthase kinase-3alpha (GSK-3alpha) in glucose metabolism: effect of strain variation. PLoS ONE 6, e15845. doi:10.1371/journal.pone.0015845

Perez-Costas, E., Gandy, J. C., MelendezFerro, M., Roberts, R. C., and Bijur, G. N. (2010). Light and electron microscopy study of glycogen synthase kinase-3beta in the mouse brain. PLoS ONE 5, e8911. doi:10.1371/journal.pone.0008911 
Piao, S., Lee, S. H., Kim, H., Yum, S., Stamos, J. L., Xu, Y., Lee, S. J., Lee, J., Oh, S., Han, J. K., Park, B. J., Weis, W. I., and Ha, N. C. (2008). Direct inhibition of GSK3beta by the phosphorylated cytoplasmic domain of LRP6 in Wnt/beta-catenin signaling. PLoS ONE 3, e4046. doi:10.1371/journal.pone.0004046

Picton, C., Woodgett, J., Hemmings, B., and Cohen, P. (1982). Multisite phosphorylation of glycogen synthase from rabbit skeletal muscle. Phosphorylation of site 5 by glycogen synthase kinase- 5 (casein kinase-II) is a prerequisite for phosphorylation of sites 3 by glycogen synthase kinase-3. FEBS Lett. 150, 191-196.

Polter, A., Beurel, E., Yang, S., Garner, R., Song, L., Miller, C. A., Sweatt, J. D., McMahon, L., Bartolucci, A. A., Li, X., and Jope, R. S. (2010). Deficiency in the inhibitory serinephosphorylation of glycogen synthase kinase- 3 increases sensitivity to mood disturbances. Neuropsychopharmacology 35, 1761-1774.

Price, M. A., and Kalderon, D. (2002). Proteolysis of the hedgehog signaling effector Cubitus interruptus requires phosphorylation by glycogen synthase kinase 3 and casein kinase 1. Cell 108, 823-835.

Prickaerts, J., Moechars, D., Cryns, K., Lenaerts, I., van Craenendonck, H., Goris, I., Daneels, G., Bouwknecht, J. A., and Steckler, T. (2006). Transgenic mice overexpressing glycogen synthase kinase 3beta: a putative model of hyperactivity and mania. J. Neurosci. 26, 9022-9029.

Qu, L., Huang, S., Baltzis, D., RivasEstilla, A. M., Pluquet, O., Hatzoglou, M., Koumenis, C., Taya, Y., Yoshimura, A., and Koromilas, A. E. (2004). Endoplasmic reticulum stress induces p53 cytoplasmic localization and prevents p53dependent apoptosis by a pathway involving glycogen synthase kinase3beta. Genes Dev. 18, 261-277.

Quelo, I., Akhouayri, O., Prud'homme, J., and St-Arnaud, R. (2004). GSK3 beta-dependent phosphorylation of the alpha NAC coactivator regulates its nuclear translocation and proteasome-mediated degradation. Biochemistry 43, 2906-2914.

Rada, P., Rojo, A. I., Chowdhry, S., McMahon, M., Hayes, J. D., and Cuadrado, A. (2011). SCF/\{beta\}TrCP promotes glycogen synthase kinase 3-dependent degradation of the Nrf2 transcription factor in a Keapl-independent manner. Mol. Cell. Biol. 31, 1121-1133.
Rogatsky, I., Waase, C. L., and Garabedian, M. J. (1998). Phosphorylation and inhibition of rat glucocorticoid receptor transcriptional activation by glycogen synthase kinase-3 (GSK-3). Species-specific differences between human and rat glucocorticoid receptor signaling as revealed through GSK-3 phosphorylation. J. Biol. Chem. 273, 14315-14321.

Ross, S. E., Erickson, R. L., Hemati, N., and MacDougald, O. A. (1999). Glycogen synthase kinase 3 is an insulin-regulated C/EBPalpha kinase. Mol. Cell. Biol. 19, 8433-8441.

Rössig, L., Badorff, C., Holzmann, Y., Zeiher, A. M., and Dimmeler, S. (2002). Glycogen synthase kinase-3 couples AKT-dependent signaling to the regulation of p21Cip1 degradation. J. Biol. Chem. 277, 9684-9689.

Rubinfeld, B., Albert, I., Porfiri, E., Fiol, C., Munemitsu, S., and Polakis, P. (1996). Binding of GSK3beta to the APC-beta-catenin complex and regulation of complex assembly. Science 272, 1023-1026.

Rylatt, D. B., Aitken, A., Bilham, T., Condon, G. D., Embi, N., and Cohen, P. (1980). Glycogen synthase from rabbit skeletal muscle. Amino acid sequence at the sites phosphorylated by glycogen synthase kinase3 , and extension of the $\mathrm{N}$-terminal sequence containing the site phosphorylated by phosphorylase kinase. Eur. J. Biochem. 107, 529-537.

Sahar, S., and Sassone-Corsi, P. (2009). Metabolism and cancer: the circadian clock connection. Nat. Rev. Cancer 9, 886-896.

Sahar, S., Zocchi, L., Kinoshita, C., Borrelli, E., and Sassone-Corsi, P. (2010). Regulation of BMAL1 protein stability and circadian function by GSK3beta-mediated phosphorylation. PLoS ONE 5, e8561. doi:10.1371/journal.pone.0008561

Saito, Y., Vandenheede, J. R., and Cohen, P. (1994). The mechanism by which epidermal growth factor inhibits glycogen synthase kinase 3 in A431 cells. Biochem. J. 303(Pt 1), 27-31.

Sakanaka, C. (2002). Phosphorylation and regulation of beta-catenin by casein kinase I epsilon. J. Biochem. 132, 697-703.

Saksela, K., Makela, T. P., Hughes, K., Woodgett, J. R., and Alitalo, K. (1992). Activation of protein kinase $\mathrm{C}$ increases phosphorylation of the L-myc trans-activator domain at a GSK-3 target site. Oncogene 7, 347-353.

Salazar, M., Rojo, A. I., Velasco, D., de Sagarra, R. M., and Cuadrado, A.
(2006). Glycogen synthase kinase3beta inhibits the xenobiotic and antioxidant cell response by direct phosphorylation and nuclear exclusion of the transcription factor Nrf2. J. Biol. Chem. 281, 14841-14851.

Salinas, P. C. (2005). Retrograde signalling at the synapse: a role for Wnt proteins. Biochem. Soc. Trans. $33(\mathrm{Pt}$ 6), 1295-1298.

Sánchez, C., Pérez, M., and Avila, J. (2000). GSK3beta-mediated phosphorylation of the microtubuleassociated protein $2 \mathrm{C}$ (MAP2C) prevents microtubule bundling. Eur. J. Cell Biol. 79, 252-260.

Sasaki, T., Taoka, M., Ishiguro, K., Uchida, A., Saito, T., Isobe, T., and Hisanaga, S. (2002). In vivo and in vitro phosphorylation at Ser-493 in the glutamate (E)-segment of neurofilament-H subunit by glycogen synthase kinase 3beta. J. Biol. Chem. 277, 36032-36039.

Scales, T. M., Lin, S., Kraus, M., Goold, R. G., and Gordon-Weeks, P. R. (2009). Nonprimed and DYRK1Aprimed GSK3 beta-phosphorylation sites on MAP1B regulate microtubule dynamics in growing axons. J. Cell. Sci. 122(Pt 14), 2424-2435.

Schaffer, B., Wiedau-Pazos, M., and Geschwind, D. H. (2003). Gene structure and alternative splicing of glycogen synthase kinase 3 beta (GSK-3beta) in neural and nonneural tissues. Gene 302, 73-81.

Sears, R., Nuckolls, F., Haura, E. Taya, Y., Tamai, K., and Nevins, J. R. (2000). Multiple Ras-dependent phosphorylation pathways regulate Myc protein stability. Genes Dev. 14, 2501-2514.

Sengupta, A., Wu, Q., Grundke-Iqbal, I., Iqbal, K., and Singh, T. J. (1997). Potentiation of GSK-3catalyzed Alzheimer-like phosphorylation of human tau by cdk5. Mol. Cell. Biochem. 167, 99-105.

Sharfi, H., and Eldar-Finkelman, H. (2008). Sequential phosphorylation of insulin receptor substrate- 2 by glycogen synthase kinase- 3 and cJun NH2-terminal kinase plays a role in hepatic insulin signaling. Am J. Physiol. Endocrinol. Metab. 294, E307-E315.

Shaw, M., and Cohen, P. (1999). Role of protein kinase $\mathrm{B}$ and the MAP kinase cascade in mediating the EGF-dependent inhibition of glycogen synthase kinase 3 in Swiss 3T3 cells. FEBS Lett. 461, 120-124.

Singh, T. J., Zaidi, T., Grundke-Iqbal, I., and Iqbal, K. (1995). Modulation of GSK-3-catalyzed phosphorylation of microtubule-associated protein tau by non-proline-dependent protein kinases. FEBS Lett. 358, 4-8.

Souza, R. P., Romano-Silva, M. A., Lieberman, J. A., Meltzer, H. Y., Wong, A. H., and Kennedy, J. L. (2008). Association study of GSK3 gene polymorphisms with schizophrenia and clozapine response. Psychopharmacology (Berl.) 200, 177-186.

Spengler, M. L., Kuropatwinski, K. K. Schumer, M., and Antoch, M. P. (2009). A serine cluster mediates BMAL1-dependent CLOCK phosphorylation and degradation. Cell Cycle 8, 4138-4146.

Spittaels, K., Van den Haute, C., Van Dorpe, J., Bruynseels, K., Vandezande, K., Laenen, I., Geerts, H., Mercken, M., Sciot, R., Van Lommel, A., Loos, R., and Van Leuven, F. (1999). Prominent axonopathy in the brain and spinal cord of transgenic mice overexpressing four-repeat human tau protein. Am. J. Pathol. 155, 2153-2165.

Spittaels, K., Van den Haute, C., Van Dorpe, J., Geerts, H., Mercken, M., Bruynseels, K., Lasrado, R., Vandezande, K., Laenen, I., Boon, T., Van Lint, J., Vandenheede, J., Moechars, D., Loos, R., and Van Leuven, F. (2000). Glycogen synthase kinase3beta phosphorylates protein tau and rescues the axonopathy in the central nervous system of human four-repeat tau transgenic mice. $J$. Biol. Chem. 275, 41340-41349.

Spittaels, K., Van den Haute, C., Van Dorpe, J., Terwel, D., Vandezande, K., Lasrado, R., Bruynseels, K., Irizarry, M., Verhoye, M., Van Lint, J., Vandenheede, J. R., Ashton, D., Mercken, M., Loos, R., Hyman, B., Van der Linden, A., Geerts, H., and Van Leuven, F. (2002). Neonatal neuronal overexpression of glycogen synthase kinase- 3 beta reduces brain size in transgenic mice. Neuroscience 113, 797-808.

Stambolic, V., Ruel, L., and Woodgett, J. R. (1996). Lithium inhibits glycogen synthase kinase- 3 activity and mimics wingless signalling in intact cells. Curr. Biol. 6, 1664-1668.

Stambolic, V., and Woodgett, J. R. (1994). Mitogen inactivation of glycogen synthase kinase- 3 beta in intact cells via serine 9 phosphorylation. Biochem. J. 303(Pt 3), 701-704.

Steuber-Buchberger, P., Wurst, W., and Kühn, R. (2008). Simultaneous Cremediated conditional knockdown of two genes in mice. Genesis 46, 144-151.

Streets, A. J., Moon, D. J., Kane, M. E., Obara, T., and Ong, A. C. (2006). Identification of an 
$\mathrm{N}$-terminal glycogen synthase kinase 3 phosphorylation site which regulates the functional localization of polycystin-2 in vivo and in vitro. Hum. Mol. Genet. 15, 1465-1473.

Su, Y., Fu, C., Ishikawa, S., Stella, A., Kojima, M., Shitoh, K., Schreiber, E. M., Day, B. W., and Liu, B. (2008). APC is essential for targeting phosphorylated beta-catenin to the SCFbeta-TrCP ubiquitin ligase. Mol. Cell 32, 652-661.

Sundqvist, A., Bengoechea-Alonso, M. T., Ye, X., Lukiyanchuk, V., Jin, J., Harper, J. W., and Ericsson, J. (2005). Control of lipid metabolism by phosphorylation-dependent degradation of the SREBP family of transcription factors by $\mathrm{SCF}$ (Fbw7). Cell Metab. 1, 379-391.

Surjit, M., and Lal, S. K. (2007). Glycogen synthase kinase-3 phosphorylates and regulates the stability of p27kip1 protein. Cell Cycle 6, 580-588.

Sutherland, C. (2011). What are the bona fide GSK3 substrates? Int. J. Alzheimers Dis. 2011, 505607.

Sutherland, C., and Cohen, P. (1994). The alpha-isoform of glycogen synthase kinase-3 from rabbit skeletal muscle is inactivated by p70 S6 kinase or MAP kinase-activated protein kinase-1 in vitro. FEBS Lett. 338, $37-42$.

Sutherland, C., Leighton, I. A., and Cohen, P. (1993). Inactivation of glycogen synthase kinase- 3 beta by phosphorylation: new kinase connections in insulin and growthfactor signalling. Biochem. J. 296(Pt 1), 15-19.

Svenningsson, P., Tzavara, E. T., Carruthers, R., Rachleff, I., Wattler, S., Nehls, M., McKinzie, D. L., Fienberg, A. A., Nomikos, G. G., and Greengard, P. (2003). Diverse psychotomimetics act through a common signaling pathway. Science 302, 1412-1415.

Taelman, V. F., Dobrowolski, R., Plouhinec, J. L., Fuentealba, L. C., Vorwald, P. P., Gumper, I., Sabatini, D. D., and De Robertis, E. M. (2010). Wnt signaling requires sequestration of glycogen synthase kinase 3 inside multivesicular endosomes. Cell 143, 1136-1148.

Takacs, C. M., Baird, J. R., Hughes, E. G., Kent, S. S., Benchabane, H., Paik, R., and Ahmed, Y. (2008). Dual positive and negative regulation of wingless signaling by adenomatous polyposis coli. Science 319, 333-336.

Takahashi, M., Tomizawa, K., Kato, R., Sato, K., Uchida, T., Fujita, S. C., and Imahori, K. (1994). Localization and developmental changes of tau protein kinase I/glycogen synthase kinase- 3 beta in rat brain. $J$. Neurochem. 63, 245-255.

Takeda, K., Takemoto, C., Kobayashi, I., Watanabe, A., Nobukuni, Y., Fisher, D. E, and Tachibana, M. (2000). Ser298 of MITF, a mutation site in Waardenburg syndrome type 2 , is a phosphorylation site with functional significance. Hum. Mol. Genet. 9, 125-132.

Tang, Q. Q., Gronborg, M., Huang, H., Kim, J. W., Otto, T. C., Pandey, A., Lane, M. D. (2005). Sequential phosphorylation of CCAAT enhancer-binding protein beta by MAPK and glycogen synthase kinase 3 beta is required for adipogenesis. Proc. Natl. Acad. Sci. U.S.A. 102, 9766-9771.

Taniuchi, M., Johnson, E. M., Roach, P. J., and Lawrence, J. C. Jr. (1986). Phosphorylation of nerve growth factor receptor proteins in sympathetic neurons and PC12 cells. In vitro phosphorylation by the cAMP-independent protein kinase FA/GSK-3. J. Biol. Chem. 261, 13342-13349.

Tanji, C., Yamamoto, H., Yorioka, N., Kohno, N., Kikuchi, K., and Kikuchi, A. (2002). A-kinase anchoring protein AKAP220 binds to glycogen synthase kinase-3beta (GSK-3beta) and mediates protein kinase A-dependent inhibition of GSK-3beta. J. Biol. Chem. 277, 36955-36961.

ter Haar, E., Coll, J. T., Austen, D. A., Hsiao, H. M., Swenson, L., and Jain, J. (2001). Structure of GSK3beta reveals a primed phosphorylation mechanism. Nat. Struct. Biol. 8, 593-596.

Terruzzi, I., Allibardi, S., Bendinelli, P., Maroni, P., Piccoletti, R., Vesco, F., Samaja, M., and Luzi, L. (2002). Amino acid- and lipid-induced insulin resistance in rat heart: molecular mechanisms. Mol. Cell. Endocrinol. 190, 135-145.

Thomas, G. M., Frame, S., Goedert, M., Nathke, I., Polakis, P., and Cohen, P. (1999). A GSK3-binding peptide from FRAT1 selectively inhibits the GSK3-catalysed phosphorylation of axin and beta-catenin. FEBS Lett. $458,247-251$.

Thornton, T. M., Pedraza-Alva, G., Deng, B., Wood, C. D., Aronshtam, A., Clements, J. L., Sabio, G., Davis, R. J., Matthews, D. E., Doble, B., and Rincon, M. (2008). Phosphorylation by $\mathrm{p} 38 \mathrm{MAPK}$ as an alternative pathway for GSK3beta inactivation. Science 320, 667-670.

Timm, T., Balusamy, K., Li, X., Biernat, J., Mandelkow, E., and Mandelkow, E. M. (2008). Glycogen synthase kinase (GSK) 3beta directly phosphorylates Serine 212 in the regulatory loop and inhibits microtubule affinity-regulating kinase (MARK) 2. J. Biol. Chem. 283, 18873-18882.

Tolnay, M., Juang, Y. T., and Tsokos, G. C. (2002). Protein kinase A enhances, whereas glycogen synthase kinase- 3 beta inhibits, the activity of the exon 2-encoded transactivator domain of heterogeneous nuclear ribonucleoprotein D in a hierarchical fashion. Biochem. J. 363(Pt 1), 127-136.

Trivedi, N., Marsh, P., Goold, R. G., Wood-Kaczmar, A., and GordonWeeks, P. R. (2005). Glycogen synthase kinase-3beta phosphorylation of MAP1B at Ser1260 and Thr1265 is spatially restricted to growing axons. J. Cell. Sci. 118(Pt 5), 993-1005.

Tung, H. Y., and Reed, L. J. (1989). Purification and characterization of protein phosphatase 1I activating kinase from bovine brain cytosolic and particulate fractions. J. Biol. Chem. 264, 2985-2990.

Turenne, G. A., and Price, B. D. (2001). Glycogen synthase kinase3 beta phosphorylates serine 33 of p53 and activates p53's transcriptional activity. BMC Cell Biol. 2, 12. doi:10.1186/1471-2121-2-12

Twomey, C., and McCarthy, J. V. (2006). Presenilin-1 is an unprimed glycogen synthase kinase-3beta substrate. FEBS Lett. 580, 4015-4020.

Tyagarajan, S. K., Ghosh, H., Yévenes, G. E., Nikonenko, I., Ebeling, C., Schwerdel, C., Sidler, C., Zeilhofer, H. U., Gerrits, B., Muller, D., and Fritschy, J. M. (2011). Regulation of GABAergic synapse formation and plasticity by GSK3beta-dependent phosphorylation of gephyrin. Proc. Natl. Acad. Sci. U.S.A. 108, 379-384.

Urs, N. M., Daigle, T. L., and Caron, M. G. (2011). A dopamine D1 receptor-dependent beta-arrestin signaling complex potentially regulates morphine-induced psychomotor activation but not reward in mice. Neuropsychopharmacology $36,551-558$.

Vandenheede, J. R., Yang, S. D., Goris, J., and Merlevede, W. (1980). ATP x $\mathrm{Mg}$-dependent protein phosphatase from rabbit skeletal muscle. II. Purification of the activating factor and its characterization as a bifunctional protein also displaying synthase kinase activity. J. Biol. Chem. 255, 11768-11774.

Viatour, P., Dejardin, E., Warnier, M., Lair, F., Claudio, E., Bureau, F., Marine, J. C., Merville, M. P., Maurer, U., Green, D., Piette, J., Siebenlist U., Bours, V., and Chariot, A. (2004).
GSK3-mediated BCL-3 phosphorylation modulates its degradation and its oncogenicity. Mol. Cell 16, 35-45.

Wang, X., Liu, X. T., Dunn, R., Ohl, D. A., and Smith, G. D. (2003). Glycogen synthase kinase-3 regulates mouse oocyte homologue segregation. Mol. Reprod. Dev. 64, 96-105.

Wang, X., Paulin, F. E., Campbell, L. E., Gomez, E., O'Brien, K., Morrice, N., and Proud, C. G. (2001). Eukaryotic initiation factor 2B: identification of multiple phosphorylation sites in the epsilon-subunit and their functions in vivo. EMBO J. 20, 4349-4359.

Watanabe, T., Noritake, J., Kakeno, M., Matsui, T., Harada, T., Wang, S., Itoh, N., Sato, K., Matsuzawa, K., Iwamatsu, A., Galjart, N., and Kaibuchi, K. (2009). Phosphorylation of CLASP2 by GSK-3beta regulates its interaction with IQGAP1, EB1 and microtubules. J. Cell. Sci. 122(Pt 16), 2969-2979.

Welcker, M., Singer, J., Loeb, K. R., Grim, J., Bloecher, A., Gurien-West, M., Clurman, B. E., and Roberts, J. M. (2003). Multisite phosphorylation by Cdk2 and GSK3 controls cyclin E degradation. Mol. Cell 12, 381-392.

Welsh, G. I., Miller, C. M., Loughlin, A. J., Price, N. T., and Proud, C. G. (1998). Regulation of eukaryotic initiation factor eIF2B: glycogen synthase kinase- 3 phosphorylates a conserved serine which undergoes dephosphorylation in response to insulin. FEBS Lett. 421, 125-130.

Welsh, G. I., and Proud, C. G. (1993). Glycogen synthase kinase-3 is rapidly inactivated in response to insulin and phosphorylates eukaryotic initiation factor eIF-2B. Biochem. J. 294(Pt 3), 625-629.

Wijnen, H., and Young, M. W. (2006). Interplay of circadian clocks and metabolic rhythms. Annu. Rev. Genet. 40, 409-448.

Wittmann, T., and Waterman-Storer, C. M. (2005). Spatial regulation of CLASP affinity for microtubules by Rac1 and GSK3beta in migrating epithelial cells. J. Cell Biol. 169, 929-939.

Woodgett, J. R. (1990). Molecular cloning and expression of glycogen synthase kinase-3/factor A. EMBO J. 9, 2431-2438.

Woodgett, J. R. (1994). Regulation and functions of the glycogen synthase kinase-3 subfamily. Semin. Cancer Biol. 5, 269-275.

Woodgett, J. R., and Cohen, P. (1984). Multisite phosphorylation of glycogen synthase. Molecular basis for the substrate specificity of glycogen 
synthase kinase- 3 and casein kinaseII (glycogen synthase kinase-5). Biochim. Biophys. Acta 788, 339-347.

Woodgett, J. R., Pulverer, B. J., Nikolakaki, E., Plyte, S., Hughes, K., Franklin, C. C., and Kraft, A. S. (1993). Regulation of jun/AP-1 oncoproteins by protein phosphorylation. Adv. Second Messenger Phosphoprotein Res. 28, 261-269.

Wood-Kaczmar, A., Kraus, M., Ishiguro, K., Philpott, K. L., and GordonWeeks, P. R. (2009). An alternatively spliced form of glycogen synthase kinase-3beta is targeted to growing neurites and growth cones. Mol. Cell. Neurosci. 42, 184-194.

Woods, Y. L., Cohen, P., Becker, W., Jakes, R., Goedert, M., Wang, X., and Proud, C. G. (2001). The kinase DYRK phosphorylates protein-synthesis initiation factor eIF2B epsilon at Ser539 and the microtubule-associated protein tau at Thr212: potential role for DYRK as a glycogen synthase kinase 3priming kinase. Biochem. J. 355(Pt 3), 609-615.

Wu, G., Huang, H., Garcia Abreu, J., and He, X. (2009). Inhibition of GSK3 phosphorylation of betacatenin via phosphorylated PPPSPXS motifs of Wnt coreceptor LRP6. PLoS ONE 4, e4926. doi:10.1371/journal.pone.0004926

Yamamoto, H., Kishida, S., Kishida, M., Ikeda, S., Takada, S., and Kikuchi, A. (1999). Phosphorylation of axin, a Wnt signal negative regulator, by glycogen synthase kinase-3beta regulates its stability. J. Biol. Chem. 274, 10681-10684.
Yamamoto, H., Kishida, S., Uochi, T., Ikeda, S., Koyama, S., Asashima, M., and Kikuchi, A. (1998). Axil, a member of the Axin family, interacts with both glycogen synthase kinase 3 beta and beta-catenin and inhibits axis formation of Xenopus embryos. Mol. Cell. Biol. 18, 2867-2875.

Yanagawa, S., Matsuda, Y., Lee, J. S., Matsubayashi, H., Sese, S., Kadowaki, T., and Ishimoto, A. (2002). Casein kinase I phosphorylates the armadillo protein and induces its degradation in Drosophila. EMBO J. 21, 1733-1742.

Yang, S. D., Huang, J. J., and Huang, T. J. (1995). Protein kinase FA/glycogen synthase kinase 3 alpha predominantly phosphorylates the in vivo sites of Ser502, Ser506, Ser603, and Ser666 in neurofilament. J. Neurochem. 64, 1848-1854.

Yang, S. D., Song, J. S., Yu, J. S., and Shiah, S. G. (1993). Protein kinase FA/GSK3 phosphorylates tau on Ser235Pro and Ser404-Pro that are abnormally phosphorylated in Alzheimer's disease brain. J. Neurochem. 61, 1742-1747.

Yao, H. B., Shaw, P. C., Wong, C. C., and Wan, D. C. (2002). Expression of glycogen synthase kinase-3 isoforms in mouse tissues and their transcription in the brain. J. Chem. Neuroanat. 23, 291-297.

Yin, L., Wang, J., Klein, P. S., and Lazar, M. A. (2006). Nuclear receptor Rev-erbalpha is a critical lithiumsensitive component of the circadian clock. Science 311, 1002-1005.

Yoshimura, T., Kawano, Y., Arimura, N., Kawabata, S., Kikuchi, A., and
Kaibuchi, K. (2005). GSK-3beta regulates phosphorylation of CRMP2 and neuronal polarity. Cell 120 137-149.

Yost, C., Torres, M., Miller, J. R., Huang, E., Kimelman, D., and Moon, R. T. (1996). The axis-inducing activity, stability, and subcellular distribution of beta-catenin is regulated in Xenopus embryos by glycogen synthase kinase 3. Genes Dev. 10, 1443-1454.

Yu, J. S., and Yang, S. D. (1994). Protein kinase FA/glycogen synthase kinase-3 predominantly phosphorylates the in vivo site Thr97-Pro in brain myelin basic protein: evidence for Thr-Pro and Ser-Arg-X-XSer as consensus sequence motifs. $J$. Neurochem. 62, 1596-1603.

Zeng, L., Fagotto, F., Zhang, T., Hsu, W., Vasicek, T. J., Perry, W. L. III, Lee, J. J., Tilghman, S. M., Gumbiner, B. M., and Costantini, F. (1997). The mouse Fused locus encodes axin, an inhibitor of the Wnt signaling pathway that regulates embryonic axis formation. Cell 90 , 181-192.

Zeng, X., Tamai, K., Doble, B., Li, S., Huang, H., Habas, R., Okamura, H., Woodgett, J., and $\mathrm{He}$ X. (2005). A dual-kinase mechanism for Wnt co-receptor phosphorylation and activation. Nature 438, 873-877.

Zhang, F., Phiel, C. J., Spece, L., Gurvich, N., and Klein, P. S. (2003). Inhibitory phosphorylation of glycogen synthase kinase-3 (GSK-3) in response to lithium. Evidence for autoregulation of GSK-3. J. Biol. Chem. 278, 33067-33077.

Zhao, X., Zhuang, S., Chen, Y., Boss, G. R., and Pilz, R. B. (2005). Cyclic GMP-dependent protein kinase regulates CCAAT enhancer-binding protein beta functions through inhibition of glycogen synthase kinase-3. J. Biol. Chem. 280, 32683-32692.

Zhou, B. P., Deng, J., Xia, W., Xu, J., Li, Y. M., Gunduz, M., and Hung, M. C. (2004). Dual regulation of Snail by GSK-3beta-mediated phosphorylation in control of epithelialmesenchymal transition. Nat. Cell Biol. 6, 931-940.

Conflict of Interest Statement: The authors declare that the research was conducted in the absence of any commercial or financial relationships that could be construed as a potential conflict of interest.

Received: 30 August 2011; accepted: 23 October 2011; published online: 16 November 2011.

Citation: Kaidanovich-Beilin $O$ and Woodgett JR (2011) GSK-3: functional insights from cell biology and animal models. Front. Mol. Neurosci. 4:40. doi: 10.3389/fnmol.2011.00040

Copyright (C) 2011 Kaidanovich-Beilin and Woodgett. This is an open-access article subject to a non-exclusive license between the authors and Frontiers Media $S A$, which permits use, distribution and reproduction in other forums, provided the original authors and source are credited and other Frontiers conditions are complied with. 